\title{
TEKS, KONTEKS DAN HERMENEUTIKA IMAMAT 18:22 DAN 20:13
}

\author{
Andreas Hauw
}

\begin{abstract}
Abstrak: Artikel ini mengaformasi larangan homoseks dalam Imamat 18:22 dan 20:13 lewat analisis teks dan konteks. Atas dasar teks dan konteks ini pula, artikel berdiskusi dengan pertanyaan-pertanyaan kaum revisionis yang menafsirkan kedua teks Imamat secara berbeda dan tidak relevan. Dalam kategori ritual, tradisi dan keadilan artikel ini menjawab keberatan-keberatan yang muncul.
\end{abstract}

Kata-kata Kunci: homoseks, kudus, kekejian

Abstract: The article affirms the prohibition of same-sex relationship through the analysis of the text and contexts of Leviticus 18:22 and 20:13. Differing views and interpretations by revisionists and the dismissal of their inappropriate analysis and categorization of ritual, tradition, and justice are also addressed in the article.

Key words: homosexuality, holiness, abomination

Isu artikel ini dipicu oleh dua hal. Pertama, dokumen yang ditulis dan didistribusikan oleh The Church of Scotland Theological Commission pada Mei 2013, mengenai hubungan seks sejenis ${ }^{1}$ dan pelayanan (selengkapnya, The Church of Scotland Theological Commission on Same-Sex Relationships and Ministry, selanjutnya CSTCSRM). ${ }^{2}$ Kedua, fenomena praktis seks sejenis yang diamati penulis akhir-akhir ini di

\footnotetext{
${ }^{1}$ Istilah seks sejenis yang dipakai di sini merujuk kepada seluruh aktivitas seks yang dikategorikan sebagai lesbian, gay, biseksual dan transgender ( $L G B T)$.Istilah ini akan dipakai bergantian dengan homoseks dan lesbianisme di mana perlu.

2 Lihat http://www.churchofscotland.org.uk/data/assets/pdf_file/0014/13811/20_THEOLOGIC AL_2013.pdf diakses 4 februari 2015
} 
Indonesia dan Singapura. ${ }^{3}$ Akan tetapi lokus artikel ini berpijak pada dokumen resmi gereja Presbyterian and Reformed Skotlandia, seperti yang disebut di atas, terutama butir 6.11 (Reflections on Specific Passages of Scripture); 7.6.3.1.8 (Leviticus 18) dan 7.6.3.5 (Old Testament Conclusion). Dengan demikian, artikel ini tidak akan membahas seluk-beluk teoritis praktek seks sejenis. ${ }^{4}$

Berkaitan dengan lokus pembahasan, maka pertanyaan yang diajukan ialah bagaimana teks Imamat 18 dan 20 seharusnya dipahami dalam kaitan isu seks sejenis? Bagaimana gereja-gereja di Indonesia

${ }^{3}$ Laporan surat kabar Kompas edisi 31 Oktober 2014 memuat perilaku sepasang calon pengantin yang harus berurusan dengan polisi karena salah satu calon diketahui berjenis kelamin sejenis. Kedua calon ini telah lama memikat tali cinta, lihat http://regional.kompas.com/read/2014/10/31/0730008/Dua.Gadis.Gowa.Diamankan.kar ena.Ingin.Menikah.Sesama.Jenis?utm_source=WP\&utm_medium=box\&utm_campaign =Kknwp Sementara itu gereja-gereja di Negara tetangga, Singapura, bereaksi dengan semakin terbukanya kampanye $L G B T$ yang "mendapat restu" dari pemerintah. Lihat surat terbuka National Council of Churches of Singapore, http://info.ncss.org/joom837/index.php/m-statements/84-statement-on-pinkdot-25-jun-2014. Secara resmi pemerintah Singapura masih mengakui dan menjunjung tinggi nilai tradisional, namun pada sisi lain pemerintah tidak melakukan usaha-usaha berarti untuk menghalangi gerakan ini. Hal ini tampak dalam kasus buku And Tango Makes Three dan The White Swan yang ada di National Library Singapore (NLS). Setelah ditentang masyarakat, akhirnya buku-buku tersebut tetap dipajang dalam rak khusus supaya tidak bisa diakses oleh anak-anak (padahal ini adalah buku cerita anakanak!). Tentang ini lihat,http://www.straitstimes.com/news/singapore/more-singaporestories/story/nlb-saga-two-removed-childrens-books-will-go-adult-secti. $\quad$ Tentang sejarah dan perkembangan gerakan $L G B T$ di Singapura lihat, http://pinkdot.sg/aboutpink-dot/

${ }^{4}$ Untuk bahasan mengenai seks sejenis pada zaman kuno dan modern,lihat David F. Greenberg, The Construction of Homosexuality (Chicago: University of Chicago Press, 1988); bahasan mengenai seks sejenis dalam budaya Yunani lihat, K. J. Dover, Greek Homosexuality (Cambridge: Harvard University Press, 1989); bahasan dari perspektif ilmu pengetahuan modern lihat artikel-artikel antara lain: John Horgan, "Eugenic Revisited." Scientific American 268 (June, 1993): 122-131 yang membahas korelasi anak kembar dengan seks sejenis; Simon LeVay, "A Difference in Hypothalamic Structure Betwen Heterosexual and Homosexual Men.” Science 253 (August 30, 1991): 1034-1037 yang melaporkan perbedaan area otak dari mereka yang melakukan seks sejenis dengan yang tidak; untuk melihat pandangan masa kini dari gereja Roma Katolik lihat Renée Mirkes, "Science, Homosexuality, and the Church." Ethics and Medics 17 (June, 1992): 1-3; untuk bahasan definisi gender dari mereka yang transgender dan interseksual, namun dipandang dari sisi ilmu pengetahuan dan teologi lihat Heather Looy dan Hessel Bouma III, "The Nature of Gender: Gender Identity in Persons Who are Intersexed or Transgendered." Journal of Psychology and Theology Vol 33 No. 3 (2005): pp.166-178. 
seharusnya bersikap dalam menanggapi isu seks sejenis yang berkembang di dalam gereja dan masyarakat, secara khusus dalam kaitan dengan teks Imamat 18 dan 20 dan keberatan-keberatan kaum revisionis (pro-homoseksual) baik yang diwakili dalam dokumen komisi teologia gereja Skotlandia atau tidak?

Untuk menjawab pertanyaan-pertanyaan di atas, artikel ini akan membahas konteks kitab Imamat 17-27 dengan memberi perhatian pada pasal 18-20. Analisis relasi Imamat 18-20 menjadi pondasi melihat teks Imamat 18:22 dan 20:13. Teks Imamat 18:22 dan 20:13 akan dievaluasi melalui beberapa kata dan frasa penting yang bisa memberikan banyak penjelasan tentang isi teks tersebut. Atas dasar diskusi konteks dan teks, artikel akan menjawab beberapa keberatan dari kelompok revisionis,yang diformulasikan dalam kategori: ritual, tradisi dan keadilan.Pada akhir artikel, penulis akan menyimpulkan pembahasan ini.

\section{KONTEKS IMAMAT 17-27}

Walter Kaiser memandang kitab Imamat sebagai sebuah buku pegangan untuk menyembah Tuhan. ${ }^{5}$ Dia membagi kitab ini menjadi dua bagian, pasal 1-16 yang ditujukan kepada para imam dan pasal 17-27 yang fokus kepada peraturan-peraturan imamat. Mengelaborasi bagian ke dua ini, Kaiser berpendapat bagian tersebut menekankan kekudusan para imam dan orang Israel agar menjadi bangsa yang kudus, yang berbeda dari bangsa-bangsa lain (Kel 19:5). ${ }^{6}$

\footnotetext{
${ }^{5}$ Walter C. Kaiser, J. R., The Book of Leviticus (NIB 1; ed. Leander E. Keck, et al. Nashville: Abingdon, 1994), p.988.

6 Kaiser, Leviticus, 987. Beberapa ahli menilai Imamat 17-26 sebagaiHoliness Codekarena bentuk sastranya dan percaya bagian ini terpisah dari bagian lain. Bagian ini dipercaya telah ada sejak lama sebelum digabungkan menjadi satu kesatuan,untuk sejarah ringkas penelitian mengenai ini lihat,John E. Hartley, Leviticus (WBC 4; Dallas, Tx.,: Word Books, 1992), 251-260;untuk hubungan Imamat 17-26 dengan Yehezkiel 40-48, lihat A. Klostermann, "Ezechiel und das Heiligkeitsgesetz." Der Pentateuch: Beiträge zu seinem Verständnis und seiner Entstehungsgeschichte. (Leipzig: U. Deichert'sche Verlagsbuchhandlung, 1893), pp.419-47.
} 
Senada dengan pendapat Kaiser tersebut, Gordon Wenham menyebut bagian kedua ini sebagai prescriptions for practical holiness ${ }^{7}$ atau, bagi John Hartley adalah Laws on holy living ${ }^{8}$ dan bertujuan memisahkan atau membedakan hal yang kudus dan tidak kudus bagi umat Israel dalam kehidupan sehari-hari. ${ }^{9}$

Tujuan ini didukung oleh motif yang tampak dalam hampir sepanjang kitab ini misalnya di Imamat 18:2, 4 dan 30 yaitu frasa "Akulah Allahmu." ${ }^{10}$ Motif ini menjadi formula yang berfungsi menaruh bagian yang bersangkutan di bawah ketaatan pada kuasa pemberi aturan yaitu Yahweh.Jadi, formula ini tidak saja mengesahkan tujuan bagian kedua kitab Imamat ini tetapi juga meneguhkan kuasa hukum ilahi di atas situasi sosio-politis.Sehingga, dengan menaati hukum ini orang-orang menyatakan kesetiaanya kepada Yahweh. ${ }^{11}$

\section{RELASI IMAMAT 18-20}

Imamat 18-20 diawali pasal 17 yang secara khusus menyoroti bagaimana cara yang tepat memberikan kurban kepada Tuhan, di sini penggunaan kurban darah mendapatkan perhatian. ${ }^{12}$ Melanjutkan pasal 17, Imamat 18 berisi aturan-aturan larangan tentang seks, yang didahului nasihat agar menaatiperintah Yahweh untuk tidak berbuat seperti orang Mesir dan Kanaan supaya mereka hidup. Motif larangan dikaitkan dengan pribadi TUHAN, yang ditemukan dalam tiga kali pemakaian frasa "Akulah TUHAN Allahmu" dalam lima ayat pertama (18:1-5). Selanjutnya, pasal ini mengatur larangan seksual di antara keluarga (618), larangan seksual ketika menstruasi (19), larangan seksual dengan

${ }^{7}$ Gordon J. Wenham, The Book of Leviticus. NICOT(Grand Rapids: Eerdmans, 1979), xi, 240 (a manual of holiness); juga R. K. Harrison, Leviticus (TOTC; Leicester: InterVarsity, 2002), p.178.

${ }^{8}$ Hartley, Leviticus, p.viii.

9 Ibid., p.248.

${ }^{10}$ Frasa ini muncul lebih dari 30 kali dalam kitab ini-di antaranya juga muncul dengan variasi lebih pendek 19:3, 4, 10, 12, 14, 16, 18, 25, 28, 30, 31, 32, 34, 36, 37; 20:7; $21: 12 ; 22: 2 ; 24: 22 ; 26: 1,2$. Juga frasa ini divariasi dengan menekankan kekudusan seperti 19:2; 20:7, 26; 21:6, 8, 15, 23; 22:9, 16, 32 .

${ }^{11}$ Hartley, Leviticus, p. 292.

${ }^{12}$ Tentang uraian susunan pasal ini lihat Baruch A. Levine, Leviticus (JPSTC; ed. Nahum M. Sarna and Chaim Potok.Philadelphia: The Jewish Publication Society, 1989), p.111. 
istri tetangga (20), larangan mempersembahkan kurban anak-anak kepada setan (21), larangan seksual sesama laki-laki (22), larangan seksual dengan hewan (23), lalu diakhiri dengan nasihat-nasihat supaya menaati hukum-hukum itu (24-30). Dalam narasi penutup ini, motif negeri tempat tinggal mereka menjadi najis dan karenanya mereka akan dimuntahkan, yaitu dihalau keluar dari negeri, jelas ditekankan (24-25, 27-29). Motif pencemaran negeri ini menyebabkan bukan saja orang Israel harus taat pada aturan-aturan yang diberikan Yahweh, tetapi juga orang asing yang tinggal di tengah-tengah mereka (26). Narasi penutup ini sekali lagi mengutip motif "Akulah TUHAN Allahmu."

Pasal 19 membahas hidup yang kudus, yang diapit oleh dua pasal aturan tentang seksual (18 dan 20). Rincian pasal 19 didasarkan pada pernyataan bahwa TUHAN itu kudus sehingga orang Israel harus menjadi umat yang kudus (19:2). Rincian hidup yang kudus itu berkaitan dengan sepuluh Hukum Musa. Kaiser memperlihatkan bahwa hukum 1 dan 2 direfleksikan di 19:4, hukum 3 tampak di 19:12, hukum 4 dan 5 ada di 19:3, hukum 6 ada di 19:16, hukum 7 ada di 19:29, hukum 8 dan 9 ada di 19:11 dan 16, hukum 10 ada di 19:18. ${ }^{13}$ Lalu ditutup dengan motif "Akulah TUHAN" (19:37).Proposal Kaiser ini cukup untuk memahami susunan pasal 19 ini, yang intinya adalah Sepuluh Hukum Musa.

Pasal 20 mengulangi larangan yang ada di pasal 18. Jacob Milgrom mendaftarkan perbedaan pasal 18 dan 20, sambil mencatat perkembangannya. ${ }^{14}$ Dengan memperhatikan karya Calum Carmichael tentang sitz im leben pasal 18 dan 20-yang berargumen hukum-hukum Pentatukh adalah murni sastra yang tidak lahir dari pergumulan masyarakat dan adalah produk pembuat hukum yang bergumul dengan tradisi-tradisi narasi Israel dari masa lalu, ${ }^{15}$ Milgrom berpendapat sebaliknya, kedua pasal ini sebagai bagian hukum-hukum Pentatukh yang muncul karena problem masyarakat yang dihadapi para pembuat hukum dalam generasinya. ${ }^{16}$ Dengan dasar ini, Migrom berpendapat ada

\footnotetext{
${ }^{13}$ Kaiser, Leviticus, p.1131.

${ }^{14}$ Jacob Milgrom, Leviticus 17-22, AB 3A (New York: Doubleday, 2001), pp.1765-68.

${ }^{15}$ Calum M. Carmichael, Law, Legend, and Incest in the Bible: Leviticus 18-20 (Ithaca: Cornell University, 1997), pp.8-9.

${ }^{16}$ Milgrom, Leviticus17-22, p.1593.
} 
perbedaan antara pasal 18 dan 20. Pasal 18:6-18 digerakkan prinsip pertalian kekerabatan dan keturunan, lalu 18:19-23 diikuti oleh aturan praktek-praktek lain tentang seks. Sementara itu pasal 20 digerakkan oleh prinsip hukuman. ${ }^{17}$ Mirip dengan pandangan Milgrom ini adalah pendapat Gagnon yang melihat bahwa pada dasarnya semua larangan di 20:10-21 telah diakomodasi dalam 18:6-23, hanya beberapa aturan yang sama sekali tidak tercantum atau hanya sedikit bersinggungan. ${ }^{18}$ Gagnon berpendapat ini mungkin terjadi karena adanya perbedaan pandangan, di mana perbedaan yang kentara adalah soal susunan dan penghukuman dari kedua pasal ini. ${ }^{19}$ Sekalipun kedua pasal tidak persis sama, namun keduanya mengemukakan aturan larangan seksual dengan masing-masing variasi. Dengan demikian tidak ada perbedaan yang kontradiktif di antara kedua pasal tersebut.

Bila kesimpulan di atas benar maka pandangan bahwa pasal 20 adalah kelanjutan dari pasal 18 atau sebaliknya berdiri sendiri-sendiri, tidak perlu dipersoalkan lagi. Jelas ada kontinuitas dan perbedaan. Mungkin posisi pasal 19 yang berada diantara kedua pasal tersebut bisa membuka kunci kebuntuan untuk memahami kontinuitas dan perbedaan itu. Mary Douglas menyatakan bahwa pasal 19 adalah pusat dari kitab Imamat, dan pasal 18-20 berfungsi sebagai titik balik dari pusat

\footnotetext{
${ }^{17}$ Milgrom, Leviticus17-22, p.1593.

${ }^{18}$ Misalnya larangan di 18:7, 10, 18 tidak terdapat di pasal 20.Sebaliknya, pasal 18 tidak mencantumkan larangan yang ada di 20:6 dan 9. Sementara itu susunan yang berbeda terdapat dalam 18:17 dengan 20:14, perbedaan pengalimatan di 18:19 dengan 20:18, perbedaan bentuk hukum apodiktik dengan orang ke-2 tunggal di pasal 18 dengan bentuk hukum kasuistik dengan orang ketiga tunggal di pasal 20; perbedaan penerima di mana pasal 20 tampak ditujukan kepada komunitas; pasal 20 cenderung merujuk kepada pasal-pasal awal seperti 20:6, 27 ke 19:26, 20:9 ke 19:2, 20:25 ke 11 dst seolah-olah pendengar telah mendapati topik ini sebelumnya namun sekarang perspektif yang disampaikan berbeda; perbedaan penghukuman dimana pasal 18 dipakai istilah kareth yaitu dihalaukan sedangkan pasal 20 bertingkat-tingkat: dihalau/kareth (ay. 17-19), dilenyapkan (ay. 9-16) dan tidak mempunyai keturunan (ay. 20-21); perbedaan alasan penghukuman di mana pasal 18 melihat secara negatif bahwa dosa membawa kepada penghalauan sedangkan pasal 20 melihat secara positif akibat dari menaati aturan-aturan yaitu mereka akan dipisahkan dari bangsa lain dan menjadi bangsa kudus (26), lihat Milgrom, Leviticus17-22, pp. 1766-67.

${ }^{19}$ Robert A. J. Gagnon, "The Old Testament and Homosexuality: A Critical Review of the Case Made by Phyllis Bird" ZAW 117. BD. , S. (2005), pp.367-94 khususnya p.378.
} 
itu. ${ }^{20}$ Setuju dengan pandangan ini, Milgrom menambahkan pasal 18 dan 20 berfungsi estetika dan ideologis yaitu menerangi dan mengumandangkan ide utama kitab ini, pasal 19. ${ }^{21}$ Sebagaimana proposal Kaiser bahwa pasal 19 berpijak dan menguraikan Sepuluh Hukum Musa, maka pendapat Douglas dan Milgrom tidak dapat diabaikan.

\title{
TEKS IMAMAT 18:22 DAN 20:13 DAN GAGASANNYA
}

Relasi Imamat 18-20 yang bertumpu pada Sepuluh Hukum Musa menjadi pondasi untuk memahami teks Imamat 18:22 dan 20:13. Kedua pasal merekam larangan seks sejenis antara laki-laki yang berbunyi,

\begin{abstract}
"Dan seorang laki-laki (zākār) tidak akan berbaring [seperti] berbaring (lổtiškab miškěbê)[dengan] perempuan itu [adalah] sebuah kekejian (tốcébāh)" (Im 18:22). ${ }^{22}$
\end{abstract}

dan,

"Bila seorang laki-laki berbaring dengan seorang laki-laki (yiškab 'et zākār), seperti dengan seorang perempuan (miškěbểišăh), keduanya sudah melakukan suatu kekejian $\left(t \hat{o}^{c} \bar{e} b \bar{a} h^{c} \bar{a} s \hat{u}\right)$, mereka

\footnotetext{
20"Poetic Structure in Leviticus" Pomegranates and Golden Bells (Fest.J. Milgrom, ed. D. P. Wright et al. Winona Lake: Eisenbrauns, 1995), 239-56.Juga "Sacred Contagion" Reading Leviticus (ed. J. F. A. Sawyer. Sheffield: Sheffield Academic Press, 1996), pp.86-106.

${ }^{21}$ Migrom, Leviticus 17-22, p.1769

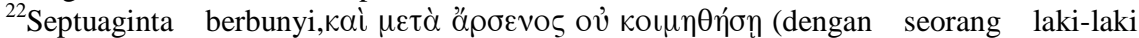

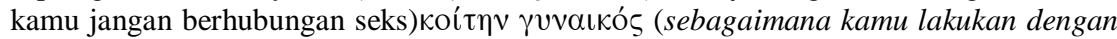
seorang perempuan, huruf miring adalah tambahan yang tidak ada secara

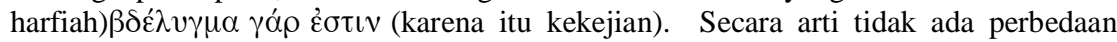

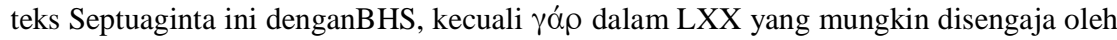

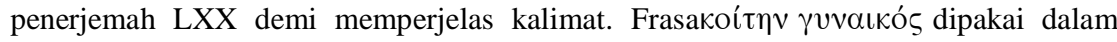
LXX Imamat 15:18 dan 19:20 dalam arti bersetubuh dengan perempuan. Jadi LXX jelas memaksudkan persetubuhan laki-laki dengan laki-laki seperti persetubuhan lakilaki dengan perempuan. Frasa yang berkaitan muncul dalam Bilangan 31:17 yang

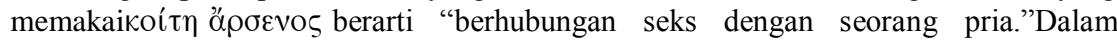
konteks Bilangan, subjek merujuk kepada perempuan "yang pernah bersetubuh dengan

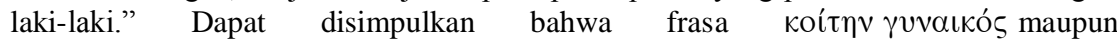

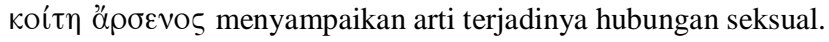


akan dihukum mati (môt yûmātû), darah mereka tertimpa kepada mereka sendiri (děmēyhem bām)" (Im 20:13). ${ }^{23}$

Kedua ayat ini jelas melarang seorang laki-laki bersetubuh dengan seorang laki-laki lain atau homoseks, seperti yang ditunjukkan oleh istilah zākār dan miškěbểišăh(jamak). Klausa "seorang laki-laki (zākār) tidak akan berbaring [seperti] (lôo tiškab miškěbê)" dan "berbaring ... seorang laki-laki(yiškab 'et zākār), seperti dengan seorang perempuan (miškěbểišāh)" dalam dua teks di atas memastikan lokusnya sebagai homoseksual. Miškěbểišăh berarti "berbaring seperti dengan seorang wanita."Membandingkan frasa miškab zākār (bersetubuh dengan lakilaki) dalam Bilangan 31:17, 18, 35 yang merujuk kepada hubungan seksual lewat vagina, maka frasa miškěbểišăh merujuk kepada penetrasi anal, ${ }^{24}$ jadi kata ini merujuk kepada konteks hubungan haram (selain Im 18:22 dan 20:13, juga dalam Kej 49:4). ${ }^{25}$ Pada dasarnya, kedua bentuk (tunggal miškab atau jamak miškěbê) bisa dipergunakan baik untuk hubungan ilegal maupun legal. ${ }^{26}$ Hal yang perlu diperhatikan di sini adalah larangan bersetubuh ditujukan kepada sesama lelaki, lesbianisme tidak disebutkan.

Larangan hubungan homoseksual ini berkaitan erat dengan Sepuluh Hukum Musa. ${ }^{27}$ Pertama, selain rekonstruksi hubungan yang telah diuraikan di atas, kedua ayat ini (Im 18:22 dan 20:13) dengan jelas menjadi petunjuk praktis dari larangan berzina dalam Sepuluh Hukum

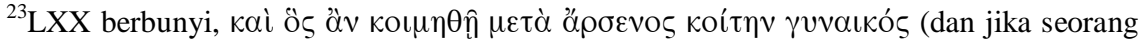
laki-laki bersetubuh sebagaimana dengan seorang

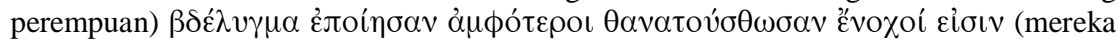
berdua melakukan kekejian pastilah mereka mati mereka bersalah).

${ }^{24}$ S. M. Olyan, "And with a Male You Shall Not Lie the Lying Down of a Woman": On the Meaning and Significance of Leviticus 18:22 and 20:13. Journal of the History of Sexuality 5 (1994), pp.183-85.

${ }^{25}$ Konteks Kejadian 49:4 adalah hubungan seksual laki-laki dengan perempuan, namun illegal.

${ }^{26}$ Kejadian 49:4 memakai bentuk tunggal untuk hubungan ilegal Ruben dengan istri ayahnya.

${ }^{27}$ Untuk diskusi hubungan semua hukum dalam PL, lihat C. J. H. Wright, Old Testament Ethics for the People of God (Nottingham: Inter-Varsity, 2004), pp.281-326.
} 
Musa (Kel 20:14, hukum ke-7). ${ }^{28}$ Kedua, secara intrinsic, kenyataan bahwa Imamat 18:6-23 dan 20:9-21 berbicara tentang berbagai persoalan perzinaan jelas berpaut kepada larangan berzina dari hukum ke-7. Jadi larangan homoseks adalah satu bagian dari sekian banyak larangan lainnya. Ketiga, larangan keras terhadap homoseks dalam Imamat 18:22 memakai konstruksi $l \hat{o}^{\jmath}$ (parallel $o u$ atau ouk dalam LXX) dan kata kerja qal imperfek yang dipakai dalam Sepuluh Hukum Musa (Kel 20:2-17). Konstruksi ini biasa dipakai dalam literatur legal/hukum di Timur Dekat Kuno (TDK), ${ }^{29}$ dan dibandingkan dengan larangan ${ }^{\circ} a l$ ( $m e \check{e}$ dalam LXX) yang bersifat temporer/kasuistik (harfiahnya "jangan") maka larangan $l \hat{o}^{\supset}$ bersifat permanen/apodiktik (bermakna "tidak akan pernah). ${ }^{30}$ Konstruksi ini tidak saja menyatakan kesamaan bentuk dengan Sepuluh Hukum Musa, ${ }^{31}$ tetapi juga menyatakan sifat kekal aturan itu dan menjadi salah satu titik perjanjian Allah dengan Israel. ${ }^{32}$ Sifat kekal perjanjian ini berlaku kepada orang Israel, tetapi juga bersifat universal.

Alasan keuniversalan larangan bersetubuh sesama laki-laki tampak dalam Imamat 20:13. Pertama, konstruksi Imamat 20:13 adalah wĕ dan

\footnotetext{
${ }^{28}$ Kitab Imamat yang menekankan kekudusan berisi rincian peraturan baik tentang persembahan maupun perilaku.Titik tolak kitab ini harus dilihat dari Keluaran 19:5-6 yang menyatakan Israel adalah milik TUHAN dan dia akan menjadi kerajaan imam dan bangsa yang kudus. Keluaran 20 yang berisi sepuluh hukum Musa diberikan sebagai patokan agar Israel menjadi milik Allah dan kudus.Dalam perspektif ini, kitab Imamat berfungsi sebagai manual untuk menerapkan Sepuluh Hukum Musa. Jadi kitab Imamat tidak lain adalah penjabaran dari Sepuluh Hukum. Pandangan ini mirip proposal Steven Kauffman untuk kitab Ulangan yang dikutip oleh Andrew E. Hill dan John H. Walton, A Survey of the Old Testament.Edisi ke- 2 (Grand Rapids: Zondervan, 2000), pp.135140.

${ }^{29}$ Bruce K. Waltke-M. O'Connor, An Introduction to Biblical Hebrew Syntax (Winona Lake: Eisenbrauns, 1990), § 31.5 [510].

${ }^{30}$ J. Weingreen, A Practical Grammar for Classical Hebrew, $2^{\text {nd }}$ ed. (Oxford: Clarendon, 1959), § 41 [77]; bdk. Page H. Kelley, Pengantar Tata Bahasa Ibrani Biblikal (terj. Andreas Hauw. Surabaya: Momentum, 2013), § 54 [187].

${ }^{31}$ K. Elliger, "Das Gesetz Leviticus 18". ZAW 67 (1955): 1-24 dan R. Kilian, Literarkritische und formgeschichtliche Untersuchung des Heiligkeitsgesetezes (Bonn: Haustern, 1963), 21-36) juga memperhatikan bentuk $l \hat{o}^{j}$ dan kata kerja qal imperfek khususnya untuk Imamat 18:7-18 sebagaimana dipakai oleh sepuluh hukum Musa dan mengkonfirmasi keterkaitannya.

${ }^{32}$ Sepuluh Hukum Musa adalah butir-butir perjanjian TUHAN dengan Israel menyusul kesepakatan antara TUHAN dengan Israel dalam Keluaran 19:5-8. Lalu TUHAN sendiri dan karya-Nya menjadi titik tolak perjanjian itu, Kel. 20:1.
} 
kata benda. Konstruksi ini berkaitan dengan konstruksi ayat 9 yang dimulai dengan $k \hat{\imath}$ (harfiah, sebab atau karena). Kata sambung $k \hat{\imath}$ menandakan sebuah permulaan umum untuk sebuah daftar yang menjangkau hingga ayat $18 .{ }^{33}$ Selain itu, munculnya kata-kata ${ }^{0} \hat{\imath}{ }^{0}{ }^{0} \hat{\imath} S$ dalam Imamat 20:9 (harfiah, laki-laki laki-laki) setelah kî., memperkuat pandangan bahwa ayat 9 ini diperlakukan sebagai judul umum untuk kalimat-kalimat berikutnya hingga ayat 18. Dari konstruksi dan isi bagian itu (ayat 9-18), maka kî mempengaruhi wĕ dalam bagian selanjutnya sebagai "protasis," yangbermakna bila atau jika. ${ }^{34}$ Makna di balik wĕ ini menyiratkan keadaan yang tidak spesifik, tidak tertuju kepada sesuatu yang telah dicurigai atau diasumsikan.Pemakaian seperti ini amat mungkin menggarisbawahi sebuah keuniversalan, yaitu siapa saja yang melakukan maka tidak diperbolehkan.

Kedua, berbeda dengan Imamat 18:22 yang menggunakan sufiks bentuk orang kedua tunggal posesif adjektif (kamu/engkau), maka larangan dalam Imamat 20:13 memakai bentuk orang ketiga tunggal (dia/seseorang). Pemakaian bentuk orang kedua tunggal membuat larangan dalam Imamat 18:22 menjadi lebih langsung dan pribadi, sehingga tidak ada sesuatu yang disembunyikan. Tujuannya adalah menekankan privacy peraturan-peraturan tersebut, dan pada pihak lain menekankan prioritas moral untuk tidak mendekati seseorang (victim) yaitu keluarga dekat untuk tujuan pelecehan seksual. ${ }^{35}$ Dari sisi pelaku, privacy ini merujuk kepada seseorang dalam keluarga dekat yang melakukan pelanggaran seksual (predator). Sementara itu, pemakaian bentuk orang ketiga tunggal dalam Imamat 20:13 merujuk kepada orang yang lebih jauh dan tidak langsung (seperti kita inklusif, bukan kami). Dengan pemakaian bernada inklusif ini, aturan larangan seolah-olah ditujukan kepada orang-orang yang ada di luar keluarga dekat atau

\footnotetext{
${ }^{33}$ GKC $§ 157 \mathrm{~b}$; Milgrom, Leviticus 17-22, p.1745.

${ }^{34}$ Bdk. NRSV yang memakai "if" mulai ayat 10-21.Bdk. wě dengan nuansa "protasis" bila atau jika, Paul Joüon-Takamitsu Muraoka, A Grammar of Biblical Hebrew, cet. ke-2, ed. ke-2.SB 27 (Roma: Gregorian \& Biblical Press, 2009), \$166b [591].

${ }^{35}$ J. R. Ziskind, “The Missing Daughter in Leviticus XVIII.” VT 46 (1996), pp.127-28.
} 
anggota komunitas umumnya. ${ }^{36}$ Dengan demikian, Imamat 20:13 adalah sebuah larangan universal.

Gambaran homoseks tampak dalam kecaman dan hukuman yang dicatat kedua ayat ini dan ayat-ayat sekitarnya. Kecaman mencakup: kekejian (tốēbāh), najis $\left(\mathrm{tm}^{\circ}\right)$, perbuatan keji atau kekejian (tebel), dan perbuatan mesum (zimmāh, Im 20:14); sedangkan hukuman mencakup hukuman mati (môt yûmātû, hanya di Imamat 20:13), dilenyapkan (kěrět), dan tidak memiliki anak ( $\left.{ }^{c} \breve{r} r \hat{r} \hat{\imath}\right)$.

Kecaman kekejian (tốēbāh) dipakai ditujukan pada semua hubungan seksual yang haram (Im 18:26-27, 29-30). Menurut Picket, kata ini menyandang beban moralitas daripada legalitas. Ia menyifatkan perlawanan ekstrem terhadap hal baik atau perilaku wajar. ${ }^{37}$ Kata kekejian dalam Imamat 18:26, 27 dan 29 menyimpulkan kecaman bagi semua larangan perzinaan dalam pasal ini. Jadi, tidak saja perzinaan antar pria yang dikecam tetapi praktek luas perzinaan. Yehezkiel 16:50 juga memakai kata tố $\hat{e}^{c} b \bar{a} h$ dalam bentuk tunggal ketika mengecam apa yang terjadi di Sodom (Yeh 16:49//Kej 19). Alasan mengecam Sodom disebabkan sikapnya yang tidak memperhatikan orang sengsara dan miskin. Jadi kesalahan Israel dalam teks ini memang merujuk kepada dosa-dosa ibadah (bdk. dengan satir Yeh 16:2-3, 8-9, 15-34) dan bukan secara eksplisit mengecam dosa seks sejenis. Akan tetapi, Yehezkiel 18:10-13 juga memakai dua kali kata kekejian, ayat 12 memakai bentuk tunggal tốēbāh sedangkan Yehezkiel 19:13 memakai bentuk jamak tốébôt. Konteks Yehezkiel 18 adalah sindiran Tuhan atas dosa-dosa Israel. Yehezkiel 18:12 menyebut beberapa dosa, kata kekejian menjadi salah satu dari daftar dosa yang disebut sebelumnya seperti menindas orang sengsara dan miskin, merampas, tidak mengembalikan gadaian orang, meminta pertolongan dari berhala-berhala. Jadi, kata kekejian dalam bentuk tunggal di Yehezkiel 18:12 merujuk kepada sebuah dosa spesifik. Sebaliknya, kata jamak kekejian dalam Yehezkiel 18:13

\footnotetext{
${ }^{36}$ Bandingkan pendapat Hartley bahwa pasal 20 ini kemungkinan ditujukan kepada komunitas, Leviticus, p.332.

${ }^{37} \mathrm{~W}$. Picket, The Meaning and Function of $T^{c} B / T O^{c} E B A H$ in the Hebrew Bible. Ph.D. diss., Hebrew Union College, 1989:127; untuk bahasan ekuivalennya dengan konsep Sumeria, lihat M. J. Geller, “Taboo in Mesopotamia” JCS 42 (1990), pp.105-17.
} 
menyimpulkan pengecaman untuk semua daftar dosa yang tertera sebelumnya, sepanjang pasal ini. Sementara itu, di Imamat 18:26-30 ditemukan empat kali kata jamak kekejian (tốébôt) yang dipakai untuk rujukan semua dosa yang terdaftar di sana (Im 18:6-23), entah ritual atau moral. Dengan membandingkan Yehezkiel 18:12-13 dengan Imamat 18:12-13, maka ada kesamaan persepsi untuk rujukan kata jamak kekejian yaitu sebutan semua dosa yang ada. Jika ini bisa diterima, maka bentuk tunggal kekejian di Yehezkiel 18:12 bila dibandingkan dengan Imamat 18:22 dan 20:13 adalah rujukan untuk dosa homoseks yang dipraktekkan di Sodom. ${ }^{38}$ Preuss mengomentari dosa-dosa di mana kata kekejian ini tunjukkan, yaitu sebagai dosa yang tidak dapat dipulihkan oleh Allah sebab dosa-dosa itu sangat berlawanan dengan karakter dan keinginan Allah. ${ }^{39}$

Kata kecaman berikut adalah $t m^{\circ}$ yang diterjemahkan najis untuk perzinaan dengan istri orang lain (ay 20), hewan (ay 23) dan gambaran negeri menjadi najis (ay 25, 27).Kecaman ini bernuansa moral (Im 19:31, 22:8, Bil 5:13, 14, 20, 27, 28, 29; Yeh 18:6, 11, 15; 33:26) dan tentu saja berakibat pada ketidaksucian ritual. ${ }^{40}$ Sebuah istilah kecaman lainnya, yang diterjemahkan dengan perbuatan keji atau kekejian (tebel), muncul dalam Imamat 18:23yang melarang perzinaan dengan hewan dan dalam 20:12, dengan menantu perempuan. Sebenarnya, tebel bisa berarti "campuran" atau "keliru"; LXX memberi arti "curang" atau "menjijikkan." ${ }^{41}$ Istilah tebel memang hanya muncul dalam dua kasus itu saja di seluruh PL, yang merujuk pada pelanggaran hukum alam karena mencampurkan dua benih yang berbeda kelompoknya atau hampir sama namun tidak sepadan sehingga memunculkan makhluk yang membingungkan. Pencampuran ini dikecam dan memalukan karena

\footnotetext{
${ }^{38}$ Robert A. J. Gagnon, The Bible and Homosexual Practice. Texts and Hermeneutics (Nashville: Abingdon, 2001), pp.82-84.

${ }^{39}$ H. D. Preuss, "תצבהת"TDOT 15:602.

${ }^{40}$ Perdebatan Carmichael, Law, 1997:52 n. 9, yang menganggap istilah $t m^{\circ}$ tidak bernuansa ritual, namun ditentang Migrom, Leviticus 17-22, 1551 Mengenai pendapat bahwa istilah ini menyangkut moral dan ritual, lihat W. F. Albright, From Stone Age to Christianity (Baltimore: John Hopkins, 1957), p.423.

${ }^{41}$ Hartley, Leviticus, 281, 284, 339. Dalam ayat ini, terjemahan LAI kemungkinan besar mengacu kepada LXX.
} 
merupakan pelanggaran kekudusan. ${ }^{42}$ Gagasan percampuran dalam tebel ini memegang peranan penting untuk memahami aturan perzinaan dalam pasal 18 dan 20.

Kata kecaman terakhir adalah zimmāh (Im 20:14), diterjemahkan perbuatan mesum. Agak sulit memastikan arti kata ini karena hanya muncul di sini dan di beberapa ayat saja seperti kitab Ayub 17:11 dan diterjemahkan rencana-rencana (Kej 11:6; Ul 19:19; Mzm 31:14; 37:12). Namun dalam konteks Imamat 20, cukup jelas kalau kata ini adalah gambaran buruk atas perilaku menikahi putri dan ibunya.

Keempat kecaman ini dipakai dalam konteks perzinaan ilegal, karena itu amat mungkin dipakai bergantian. Keempat kecaman berbeda ini menggambarkan telah terjadi praktek perzinaan secara luas dan adanya persoalan moralitas dan ritual yang buruk. Secara khusus, kecaman tố $\bar{e} b \bar{a} h$ untuk kasus homoseksual telah menggambarkan "sesuatu yang TUHAN sendiri merasa jijik."Oleh sebab itu, praktek ini amat dibenci dan dikutuk oleh TUHAN. Ia diperingati secara keras, di tengah-tengah praktek perzinaan ilegal lainnya.

Tidak heran kalau para pelanggar aturan perzinaan ini dikenai hukuman berat, khususnya pelanggar seks sejenis yang dihukum mati (môt yûmātû, Im 20:13). Namun Imamat 18:22 tidak menyebutkan hukuman mati melainkan kecaman "kekejian". Perbedaan ini terjadi karena prinsip yang mengatur Imamat 20 adalah penghukuman, sementara Imamat 18 diatur oleh prinsip kekerabatan atau keluarga dekat. ${ }^{43}$ Prinsip penghukuman yang mengatur Imamat 20 didasarkan pada

\footnotetext{
${ }^{42}$ Milgrom, 17-22, p.1571., Bdk. Hartley, Leviticus, 298. S. F. Bigger, "The Family Laws of Leviticus 18 in Their Setting.” JBL 98 (1979), 203 yang mencatat Alkitab mengutuk pencampuran dua spesies dan peran social.

${ }^{43}$ Menurut A. J. Phillips, prinsip kekeluargaan atau kekerabatan tampak dalam dua hal. Pertama, aturan larangan seksual dalam ayat 6-17a yang kental dengan praktek inses, sementara ayat 19-23 adalah larangan seks khusus (menurut Hartley, kekhususannya bertumpu pada perbuatan seks itu sendiri,Leviticus, 289). Kedua, aturan-aturan ini ditujukan dan akan diterapkan oleh kepala keluarga (bdk. 2 Sam 14:4-11; 15:1-6; 2 Raj 8:1-6; 1 Sam 20:6-21); lihat, "Some Aspects of Family Law in Pre-exilic Israel."VT 23 (1973), 349-61.Untuk gambaran mengenai bet ${ }^{\circ} \bar{a} b$ (rumah bapak) secara sosiologis, lihat L. E. Stager, "The Archeology of the Family in Ancient Israel."BASOR 260 (1985):1-35; K. van der Toorn, Family Religion in Babylonia, Syria and Israel. (Leiden:Brill, 1996),195-97; N. K. Gottwald, The Tribes of Israel: A Sociology of the
} 
keseriusan pelanggaran. Hukuman mati (môt yûmātû) diterapkan untuk pelanggaran yang disebut dalam ayat 10-16 (zina dengan istri sesama, istri ayah, menantu perempuan, sesama lelaki, perempuan dan ibunya, binatang); hukuman dilenyapkan (kěrět) diterapkan untuk pelanggaran ayat 17-18/9 (zina dengan saudarinya, perempuan menstruasi, tante atau bibi); hukuman tidak akan memiliki anak (“ărîrî) diterapkan untuk pelanggaran ayat 20-21 (zina dengan istri paman, istri saudara). ${ }^{44}$ Hartley mengelaborasi elemen-elemen dalam stuktur pola penghukuman ini yaitu: kasus, hukuman, alasan dan formula hukuman. ${ }^{45}$ Elemenelemen ini terdapat dalam ayat 13 dengan pola yang sedikit terbalik yaitu: kasus, alasan, hukuman dan formula. Dengan perbedaan prinsip di antara kedua pasal, maka tidak mengherankan kalau Imamat 18 tidak menyebut môt yûmātû. Yehezkiel 18:13 memakai terminologi môt yûmāt untuk pelanggaran yang ditulis ayat 10-16. Pelanggaran tersebut menjadi terang bila dibandingkan pernyataan positif ayat 5-9, yaitu kebalikan dari pelanggaran di ayat 10-16. Penghukuman ini dikenakan kepada kedua (̌̌ěnêyhēm) pelaku homoseks. Šĕnêyhèm menekankan bahwa bukan saja pihak aktif dalam hubungan homoseksual tetapi pihak pasif juga bersalah karena membuka peluang perhatian. ${ }^{46}$ Hukuman yang berbeda-beda ini merefleksikan adanya standar moral, jadi larangan homoseksual bukan sekadar urusan ritual.

Religion of Liberated Israel, 1350-1050 B.C.E.(Maryknoll: Orbis, 1979), 285-92. Untuk susunan lain Imamat 18 ini, lihat Hartley,Leviticus, 289. Studi mengenai hubungan kekerabatan, lihat S. Rattray, "Marriage Rules, Kinship Terms and Family Structure in the Bible."SBLSP26 (ed. K. Richards. Atlanta:Scholars, 1987), 537-44, dia menemukan bahwa larangan inses hanya dibatasi dalam empat generasi.

${ }^{44}$ Lihat D. Z. Hoffmann, Leviticus (trans. Z. Har-Shafer and A. Lieberman. Jerusalem: Mosad Harav Kook, 1954). Usulan pola lain diajukan oleh D. Daube, "Codes and Codas in the Pentateuch." Juridical Review 53 (1941), 242-61; M.Douglas, "The Stranger in the Bible."Archives europeénnes de sociologie 35 (1994), p.293.

${ }^{45}$ Hartley, Leviticus, 360; juga diikuti Milgrom, Leviticus 17-22, p.1743.

${ }^{46}$ Ketidaksenangan kaum revisionis terhadap hukuman mati yang ditulis kitab Imamat disuarakan oleh James Michener, seperti dikutip oleh Milgrom, Leviticus 17-22, 1749 50; juga diikuti oleh Bruce V. Malchow, "Scripture as a Norm of Moral Deliberation and Its Application to Homosexuality." Currents in Theology and Mission 31:6 (2004), pp.471-2. 
Dari kedua teks kita, tanpa eksegesis ${ }^{47}$ yang rumit, maka amat kasat mata bahwa ayat-ayat tersebut melarang homoseksual. Namun bukan karena eksegesis yang menjadi persoalan sehingga sebagian orang menolak dua teks ini sebagai tidak adekuat melarang homoseksual. Keberatan yang diajukan adalah soal hermeneutis dengan segala kaitannya. Bagian berikut mengelaborasi beberapa permasalahan dan counter-arguments keberatan-keberatan itu.

\section{LARANGAN HOMOSEKSUAL DAN MASALAH HERMENEUTIKA}

Mengingat keberatan hermeneutis selalu dapat diajukan dari berbagai aspek dan perspektif, maka saya mengategorikannya dalam tiga hal utama saja yaitu: ritual, tradisi dan keadilan.

\section{RITUAL}

Teks Imamat tidak adekuat melarang homoseksual karena konteksnya adalah dosa ritual. ${ }^{48}$ Dengan kata lain, teks-teks Imamat sebagai bagian Holiness Code menekankan agar Israel menjadi bangsa yang kudus, berbeda dari bangsa-bangsa lain yang ada di sekitarnya. ${ }^{49} \mathrm{Hal}$ ini penting sebab Israel adalah bangsa milik Allah yang kudus, mereka tinggal di tanah yang kudus, sehingga mereka dan negri mereka tidak

\footnotetext{
${ }^{47}$ Saya memahami eksegesis sebagai usaha untuk memahami apa yang dulu dimaksudkan oleh penulis teks. Sedangkan hermeneutik saya definisikan sebagai usaha memahami bagaimana teks yang ada dapat dipahami dan diterapkan oleh pembaca masa kini. Lihat Gordon Fee, New Testament Exegesis (terj. Andreas Hauw. Malang: Literatur Saat, 2011), p.1.

${ }^{48}$ CSTCSRM, p.52.

${ }^{49}$ Tentang konsep kekudusan, beberapa sarjana mengaitkan larangan homoseksual dengan identitas (boundaries) Israel yang menjadi kabur (lihat M. Douglas, Purity and Danger. London: Routledge \& Kegan Paul, 1966:29; T. M. Thurston, "Leviticus 18:22 and the Prohibition of Homosexual Acts." Homophobia and the Judaeo-Christian Tradition, ed. M. L. Stemmeler dan J. M. Clark.Dallas: Monument, 1990:7-23), mencampurkan benih kehidupan (semen) dengan cairan lain yang najis (S. F. Bigger, "The Family Laws of Leviticus 18 in Their Setting." JBL 98:188-203. 1979; D. Daube, Studies in Biblical Law. Cambridge: CUP, 1947:74-101; S. M. Olyan menyebutkan larangan lebih kepada kecemaran pribadi dari pada kecemaran negri akibat perbuatan ini, lihat "And with a Male You Shall Not Lie the Lying Down of a Woman": On the Meaning and Significance of Leviticus 18:22 and 20:13. Journal of the History of Sexuality 5 (1994), p.205.
} 
boleh menjadi najis. ${ }^{50}$ Jadi, aturan-aturan di Imamat berfungsi sebagai bagian ritual agar kekudusan bisa terwujud. Misalnya,larangan berhubungan seksual dengan perempuan menstruasi (Im 18:19; 20:18) menyebabkan tumpahan darah dan sperma yang menajiskan pasangan tersebut dan negri tempat tinggal mereka. ${ }^{51}$ Atas dasar ritual inilah maka homoseks dilarang, sebab berkaitan dengan penyembahan berhala. ${ }^{52}$

Pertanyaan yang harus diajukan untuk menyanggah pendapat ini adalah: apakah homoseks berkaitan dengan ibadah kepada dewa-dewi tertentu atau merupakan perilaku sosial umum?

Perjanjian Lama mencatat adanya kaitan antara seks sejenis dengan ibadah kepada dewa-dewi tertentu, walaupun praktek itu belum pasti terjadi di antara orang Israel. ${ }^{53}$ Ulangan 23:17-18 [MT ay. 18-19] mencatat larangan terhadap orang Israel menjadi pelacur bakti (qědēšah, harfiah: wanita suci) dan semburit bakti (qadēš, pria suci). Dalam teks yang sama, juga ada larangan membawa upah sundal (zônah) dan uang semburit (měhîr keleb, harfiah, bayaran seekor anjing) ke rumah TUHAN. Karena praktek pelacur bakti ini (laki-laki maupun perempuan) dilarang dan adalah hasil pengaruh orang-orang Kanaan kuno (bdk.Kej

\footnotetext{
${ }^{50}$ Ketidakkudusan menyebabkan tanah terpolusi, Imamat 19:25, 27 dan 28.

${ }^{51}$ H. Eilberg-Schwartz, The Savage in Judaism. Bloomington: Indiana University Press, 1990:183; D. Biale, Eros and the Jews. New York: Basic Books, 1992:29. Tumpahan sperma ini juga dipandang sebagai penyia-nyian sperma yang menjadi alasan motif prokreasi mempersalahkan bukan saja hubungan dengan perempuan menstruasi tetapi juga hubungan homoseks, lihat tentang argumentasi pro-kreasi dalam Migrom, Leviticus 17 22, p. 1567.

${ }^{52}$ N. H. Snaith, Leviticus and Numbers.London: Nelson, 1967:126; J. Boswell, Christianity, Social Tolerance, and Homosexuality. Chicago: University of Chicago, 1980, p.100.

${ }^{53}$ Hukum Hammurabi dari 1726 B. C. E. menyebutkan praktek adopsi anak laki-laki oleh sida-sida kerajaan, sejauh ini dokumen inilah yang tertua berkaitan dengan kemungkinan praktek homoseksual yang dapat diketahui. Sementara itu hukum orangorang Het pada millennium yang sama juga mengijinkan perkawinan sejenis. Di Babilonia ditemukan kalender mantera yang berisi doa-doa pujian cinta pria terhadap pria lain, atau pujian pria terhadap wanita, atau sebaliknya.Situasi di Mesir tidak mudah, tidak ada bukti kalau para Firaun baru bermasturbasi atau disodomi oleh imam kepala. Namun ada kepercayaan bahwa hubungan seks sejenis dengan seorang dewa akan mendatangkan kelimpahan yang besar. Di Yunani pada abad 6 B. C. E. homoseksual telah menjadi bagian hidup. Lihat lebih lanjut penjelasan ringkas Rose Ann Bast, "Homosexuality," International Encyclopedia of Ethics (ed. John K. Roth. LondonChicago:Fitzroy Dearborn, 1995), pp.394-97.
} 
19 dan Hak 19), maka diyakini imam kafir yang disebut qěděšim melakukan praktek homoseks secara regular (bdk. 1 Raj 14:24, 15:12, 22:47; 2 Raj 23:7 dan Ayb 36:14). Praktek ini menghasilkan měhîr keleb yaitu upah pelacur pria yang melayani prialain-homoseks, bukan melayani wanita. Jadi PL mengonfirmasi adanya ritualitas yang melibatkan homoseksual di kalangan non-Israel.

Konfirmasi PL bahwa praktek homoseks berkaitan dengan ritual telah dipakai kaum revisionis sebagai alasan bahwa selama homoseksual tidak bersangkutan dengan ibadah berhala maka perilaku itu harus dianggap sah dan tidak berdosa. Gagasan ini sangat keliru. Pertama, kitab Imamat melarang semua hubungan seks sejenis (non-ritual)dan kitab Ulangan melarang semburit bakti (ritual). Nissinen menunjukkan bahwa dengan memakai istilah "bayaran untuk seekor anjing," penulis kitab Ulangan telah menolak praktek homoseksual dengan merendahkan pelakunya. ${ }^{54}$ Kedua, seperti telah dikemukakan sebelumnya, teks-teks Imamat tidak saja melarang hubungan homoseks tetapi semua praktek seksual haram. Ketiga, aturan Imamat ini ditujukan kepada semua lakilaki (zākār) bukan pada qědēšim saja, yang mempraktekkan homoseks di kuil-kuil mereka. Keempat, perbedaan hukuman untuk setiap pelanggaran berbeda (Im 20) menunjukkan adanya standar moral yang dipakai. Kelima, pertimbangan kaum revisionis yang bergantung pada ada tidaknya relasi dengan ritual tidak bisa dibenarkan karena homoseks dilarang bukan atas dasar adanya relasi atau asosiasi dengan ritual di sekeliling Israel, homoseks dilarang karena menyangkut moralitas. Misalnya, banyak cara persembahan kurban orang Kanaan yang mirip dengan cara persembahan di Israel namun keduanya memiliki batasan, salah satunya adalah batasan moral sehingga persembahan anak dilarang di Israel karena dipandang tidak bermoral. Apa yang tersisa dari pertanyaan "apakah homoseks berkaitan dengan ritual atau perilaku sosial umum" adalah jawaban, bahwa homoseksual memang menjadi bagian ritualitas non-Israel tetapi juga sekaligus perilaku sosial yang terjadi di

\footnotetext{
${ }^{54}$ Lihat Martti Nissinen, Homoeroticism in the Biblical World: A Historical Perspective (Minneapolis: Augsburg Fortress, 1998),34; lihat juga Gagnon, Homosexual Practice,pp.49, 109, 131.
} 
antara orang Israel. ${ }^{55}$ Atas alasan inilah kitab Imamat melarang homoseksual karena praktek tersebut mengindikasikan adanya pelanggaran moral di samping ritual, baik alasan moral atau ritual telah menyebabkan orang Israel tidak kudus.

\section{TRADISI}

Teks Imamat tidak adekuat melarang homoseksual karena aturanaturan lain di dalam teks itu tidak lagi dipraktekkan pada masa kini. Dengan kata lain, aturan-aturan dalam Imamat adalah hukum-hukum sipil Israel kuno jadi tidak relevan pada masa kini. Inti dari keberatan pada bagian ini ialah pertanyaan untuk siapa sebenarnya aturan-aturan di Imamat itu? Jawaban kaum revisionis adalah untuk masyarakat Israel kuno, ${ }^{56}$ sehingga melarang homoseksual diterapkan masa kini hanyalah didasarkan pada prasangka.Teks Imamat tidak bermaksud melarang praktek itu.

Ada dua bukti yang ditunjukkan kaum revisionis mengenai tradisi. Pertama, tidak adanya perlakuan seragam dalam aturan-aturan Imamat. Pada satu pihak kitab Imamat melarang orang memakai pakaian yang dibuat dari dua jenis bahan (19:19), atau larangan mencukur rambut dan tepi janggut (19:27) dan hukuman mati bagi anak yang mengutuk ayah ibunya (20:9), namun aturan-aturan itu tidak lagi dipraktekkan sekarang. ${ }^{57}$ Pada pihak lain, homoseks dilarang dan dihukum. Maka persoalannya adalah mengapa hanya larang homoseks yang masih berlaku hingga masa kini?

\footnotetext{
${ }^{55}$ Para Rabi kemudian hari menulis bahwa ketika Musa melarang orang Israel melakukan pernikahan terlarang ini, maka mereka menjadi susah (Sipre Num 90; $b$ Yoma 75a). Ini merefleksikan adanya pelanggaran serius dan terjadi di tengah masyarakat Israel.

${ }^{56}$ Motivasi amat penting ketika berhadapan dengan banyak aturan di dalam PL yang mungkin saja tidak relevan lagi bagi kita sekarang. Namun Paulus (Gal. 3:24) berpendapat bahwa PL termasuk aturan-aturan yang ada di dalamnya adalah petunjuk bagi kita dan bermanfaat. Karena itu gereja seharusnya bertanya apa yang bisa saya pelajari dari aturan-aturan yang tampak tidak relevan sekarang? Apa yang Allah mau dariku dan kelompokku lewat aturan-aturan ini? Bukan pertanyaan, mana dari aturanaturan ini yang bisa diabaikan dan tidak perlu ditaaati? Sebab banyak aturan-aturan dalam PL tercipta karena kebutuhan masyarakat sendiri, dan karena itu bisa menghasilkan kehidupan harmonis antar sesama.

${ }^{57}$ Lihat catatan kaki 42.
} 
Dalam bagian sebelumnya telah dinyatakan bahwa aturan-aturan Imamat bersifat universal, ${ }^{58}$ diterapkan untuk orang Israel dan orang asing di Israel. Jadi tidak berdasarkan suka atau tidak suka tetapi komitmen kesatuan (sebagai bangsa atau iman kepada Yahweh). Implikasi aturan yang universal ini adalahsemua aturan dalam Imamat adalah sejajar, semua harus dilakukan. Jika demikian, bagaimana dengan aturan-aturan yang tidak lagi dilakukan dan diikuti gereja masa kini seperti disebutkan dalam contoh di atas?

Ada dua kekeliruan yang perlu ditunjukkan. Jika berpendapat bahwa karena sekarang ada aturan yang tidak diberlakukan lagi sehingga mengakibatkan aturan tentang homoseksual juga tidak berlaku lagi, maka terjadi kekeliruan logika. Kekeliruan itu dapat dijelaskan dengan pertanyaan sebagai berikut, apakah aturan perzinaan lainnya dalam Imamat juga harus dibatalkan? Apakah aturan tentang pencurian juga seharusnya tidak berlaku lagi? Apakah aturan larangan membunuh harus ditiadakan juga? Dan pertanyaan-pertanyaan serupa dapat dilanjutkan. Kenyataan bahwa sampai hari ini, banyak individu dan kelompok (sekular atau agama) tidak pernah bermaksud mau melegitimasi perzinaan inses atau melegalkan perbuatan kriminal lainnya, telah membuktikan bahwa logika yang dipakai dalam keberatan kaum

\footnotetext{
${ }^{58}$ Disampaikan John Beem pada The Greater Milwaukee Synod 18 Februari 2001, seperti dicatat Malchov, "Scipture as a Norm," 471.Malchov berpendapat Imamat 18:3 menentang keuniversalan aturan Imamat 18:22 (dan Im 20:13). Saya tidak memahami apa maksud Malchov mengatakan ini, sebab ayat 3 berbicara tentang situasi di mana orang Israel harus berbeda dari bangsa-bangsa sekelilingnya.Jika Malchov bermaksud bahwa ayat ini menentang keuniversalan aturan-aturan lain, maka dia salah kaprah mendefinisikan hukum.Keuniversalan aturan di Imamat memang berlaku untuk orang Israel namun juga untuk bangsa-bangsa lain.Larangan agar berbeda dari bangsa-bangsa asing di sekitar Israel tidak serta merta berarti aturan-aturan Imamat tidak universal.Dibalik larangan itu, bukanlah hukum yang mati tetapi diri Allah sendiri yang menyatakan diri-Nya kudus. Seandainya orang Israel harus sama dengan bangsa-bangsa lain di sekitarnya dan baru bisa diartikan bahwa hukum Imamat bersifat universal, maka Malchov keliru mendefinisikan apa arti hukum.Hukum Imamat berlaku universal selama individu atau kelompok mengakui Yahweh sebagai Tuhan, tidak dibatasi oleh ras.Sebab sebuah hukum berlaku atas pribadi-pribadi yang terikat pada sesuatu.Masalah dengan Malchov adalah tidak mengakui aturan Imamat tetapi berada dalam komunitas yang terikat dengan hukum/aturan itu. Perdebatan di The Greater Milwaukee Synod tentang homoseksualitas yang terjadi dua kali (tahun 2000 dan 18 Februari 2001) diakhiri dengan voting untuk meyetujui pemberkatan nikah sejenis.
} 
revisionis adalah keliru. Sejumlah aturan-aturan di Imamat memang berkaitan dengan simbol, misalnya peraturan tentang makanan haram, peraturan tentang dua jenis bahanpakaian danmodel rambut. Perjanjian Baru, Yesus dan Paulus telah meratifikasi aturan tentang makanan di Imamat (lihat Mrk 7:18-23; Kis 10:9-16; 1 Kor 8:1-13) karena makanan menjadi tanda yang memisahkan antara orang Israel dengan non-Israel. Ratifikasi itu telah membuat aturan tentang makanan di Imamat tidak lagi relevan sekarang. Hal yang sama juga terjadi dengan aturan tentang dua jenis pakaian dan model rambut. Keduanya adalah simbol dan dilarang karena terjadi percampuran (tebel) yang akan dijelaskan kemudian. Akan tetapi masalah homoseks bukanlah sebuah simbol atau sama seperti masalah moral lainnya.Yesus dan Paulus dengan tegas mengafirmasi relevansinya pada masa kini, mereka mengkonfirmasi Sepuluh Hukum Musa.

Kekeliruan berikutnya adalah menyangka larangan homoseksual sebagai berasal dari kitab Imamat. Larangan homoseks harus dilihat dari perspektif lebih luas, bukan saja Sepuluh Hukum Musa tetapi seluruh kitab Musa. Jadi, larangan homoseks bermuara pada ajaran Tuhan tentang tujuan seks yang saling melengkapi pada penciptaan manusia. Dalam penciptaan, bukan hanya Adam yang adalah gambar Allah melainkan juga Hawa. Keduanya adalah gambar Allah yang merefleksikan kebersamaan dan kesejajaran. Keduanya saling melengkapi untuk tugas beranak cucu dan memelihara alam semesta. Gambar Allah dan amanat budaya inilah yang menjadi cermin dan tuntutan perilaku seksual manusia, sehingga perilaku seksual manusia berkarakter heteroseks, monogami, bukan inses, diafirmasi secara sosial dan disaksikan di hadapan orang lain, bersifat fisik dan permanen (Kej 2:24). ${ }^{59}$ Dengan demikian, tradisi larangan homoseksual bersumber pada gambar Allah dan amanat budaya yang telah ditetapkan oleh Tuhan sendiri dalam penciptaan.

Kedua, larangan homoseksual tidak cocok dengan situasi modern saat ini. Ada dua perhatian kaum revisionis, yaitu populasi dan

\footnotetext{
${ }^{59}$ C. J. H. Wright, "Sex in Leviticus: It's Part of a much Broader Teaching in Scripture." Christianity Today (July/August, 2013), p.33.
} 
pembatasan aplikasi. Kedua perhatian ini didukung argumentasi yang berbeda. Berkaitan dengan populasi, pada satu sisi kaum revisionismemandang larangan homoseksual disebabkan melanggar perintah pro-kreasi, "beranak cuculah" (Kej 1:28) dan melanggar kekudusan negri tempat mereka tinggal. Perlu dicatat, selain faktor teologis pro-kreasi faktor keamanan dan ekonomis juga amat penting bagi Israel kuno yang dikelilingi sejumlah bangsa asing, baik di dalam negri maupun di perbatasan Kanaan, dan ekonomi yang mengandalkan agrikultur tradisional dengan kebutuhan banyak pekerja. Jadi dapat di mengerti kalau masyarakat Israel kuno terobsesi mengembangkan tingkat populasi. Obsesi ini dicapaidengan usaha agar struktur keluarga besar tidak hancur, caranya adalah lewat aturan larangan hubungan seksual di dalam keluarga (misal, kemenakan-bibi, kakek-cucu perempuan, ibu tiriputra tiri, tetapi juga kemenakan-paman, kakek-cucu laki-laki, ayah tiriputra tiri). Pada sisi lain, perintah pro-kreasi dilanggar ketika benih kehidupan yaitu sperma (juga sel telur) terbuang sia-sia. Penyia-nyiaan benih kehidupan ini tidak saja melanggar pro-kreasi tetapi menajiskan pelakunya dan negri.Dua situasi ini menjadi sebab mengapa homoseks dilarang di kitab Imamat.

Akan tetapi, kedua situasi ini menjadi tidak relevan saat ini ketika terjadi peledakan penduduk ${ }^{60}$ dan ketidakkudusan dapat dihindari. Cukup jelas sekarang bahwa situasi populasi dunia menjadi persoalan bukan karena kekurangan penduduk tetapi karena kelebihan. Tetapi apakah alasan pro-kreasi menjadi satu-satunya sebab sehingga homoseksual dilarang? Mengenai kenajisan atau ketidakkudusan, jika didapatkan cara sehingga hukum ini tidak melanggar, apakah berarti homoseksual berarti sah dilakukan? Berkaitan dengan ini, apakah kekudusan juga adalah satusatunya faktor sehingga homoseks dilarang dalam kitab Imamat?

Pandangan di atas kurang lengkap. Dalil pro-kreasi memang amat mendukung bagi alasan pelarangan homoseksual, dan beberapa larangan

\footnotetext{
${ }^{60}$ Lihat catatan kaki 49, Migrom adalah salah satu sarjana pendukung pro-kreasi dengan keberatan mengenai populasi saat ini, lihat Leviticus 17-22, 1566-70; 1785-90 dan 1530-31. Philo juga menyebutkan pelarangan homoseksual karena alasan pro-kreasi, lihat Laws 3.39.
} 
seks lainnya seperti terhadap perempuan menstruasi dan hewan. Demikian pula dalil kekudusan pastilah menjadi alasan mengapa banyak larangan seksual diberlakukan, tidak saja homoseks. Akan tetapi, selain kedua faktor tersebut, faktor penting lain adalah gagasan tebel ("campuran, keliru, curang atau menjijikkan") seperti telah disinggung sebelumnya.

Tebel adalah sebutan kecaman bagi hubungan seksual dengan hewan (Im 18:23) dan mertua terhadap menantu perempuan (Im 20:12). Beberapa kasus lain yaitu mengawinkan dua jenis hewan yang berbeda, dua tanaman berbeda, dan memakai dua jenis bahan pakaian yang berbeda haruslah dikategorikan dalam praktek tebel, walaupun istilah ini tidak muncul di kasus-kasus yang disebutkan (Im 19:19). Larangan mencampurkan dua jenis bahan pakaian adalah sama dengan larangan mengawinkan dua jenis hewan atau tanaman berbeda. Alasan larangan ini adalah karena pencampuran tersebut dipandang sebagai kekejian.Pada dasarnya, seluruh aturan larangan perzinaan dalam Imamat 18 dan 20 dapat dikategorikan dan dituduh sebagai tebel.Misalnya, hubungan seksual dengan perempuan menstruasi dipandang sebagai tebel karena mencampurkan dua zat yang tidak sepadan (darah dan sperma); larangan mempersembahkan kurban anak kepada dewa asing adalah mencampurkan dua hal yang berbeda yaitu anak Israel kepada dewa nonIsrael dan keduanya berbeda atau tidak kompatibel.Namun pencampuran juga dilarang dalam kasus di mana dua hal justru tampak serupa namun sebenarnya sangat bertolak-belakang.Misalnya, larangan bersetubuh dengan istri tetangga adalah usaha mencampurkan sesuatu yang tidak diperuntukkan bagi masing-masing pihak karena keduanya tidak saling memiliki, jadi tidak kompatibel.Contoh lain adalah praktek homoseksual, yangtidak lain adalah mencampurkan dua jenis kelamin yang sama namun tidak kompatibel (salah seorang pria dalam praktek homoseksual dijadikan perempuan yang bukanlah kodratnya). Juga larangan berzina dengan kerabat terdekat (Im 18:6), tante atau bibi (Im 18:12; 20:19) dipandang sebagai mencampurkan dua hal yang tidak kompatibel, di mana masing-masing pihak berbeda dalam anatomi tubuh, potensi seksualitas dan ciri kepribadian. 
Gagasan pro-kreasi dan penyia-nyiaan benih kehidupan (kenajisan) menimbulkan banyak pertanyaan.Misalnya, bagaimana dengan tumpahan sperma yang dilakukan pasangan heteroseksual yang menikah resmi?Bagaimana dengan hubungan heteroseksual yang legal saat sang istri dalam keadaan hamil dan berarti tidak bisa membuahkan benih baru? Bagaimana dengan pandangan masyarakat TDK yang tidak mengaitkan homoseksual dengan pro-kreasi tetapi pada kompromi identitas, dan memandangnya sebagai tabu ${ }^{61}$ Di samping pertanyaan di atas, kejanggalan pandangan terjadi khususnya pada Milgrom (yang mendukung larangan homoseksual karena alasan pro-kreasi dan penyianyiaan benih kehidupan) yang justru menerima lesbianisme dan menganjurkan mereka bisa punya anak melalui inseminasi atau adopsi, anjuran yang sama juga ditujukan kepada kaum homoseks, dan memandang masturbasi tidak bermasalah menurut hukum Imamat. Alasannya menerima lesbianismeadalah karena tidak terjadi pembuangan benih kehidupan dalam praktek tersebut. ${ }^{62}$ Pandangan ini terbantahkan secara biologis, di mana ada sel telur yang dikeluarkan dalam rahim perempuan ketika orgasme dicapai, entah didapat karena stimulasi pasangan lesbiannya atau diri sendiri (masturbasi). Sementara itu, pada kasus masturbasi pria, jelas ada praktek pembuangan benih kehidupan secara sia-sia.

Ketidakkonsistenan pandangan Milgrom menjadi lebih jelas ketika ditanyakan: jika memang pro-kreasi adalah alasan homoseksual dilarang mengapa menganjurkan pasangan lesbian dan homoseks mengadopsi anak? Dengan kata lain, jika memang pro-kreasi menjadi alasan homoseksual dilarang, bukankah dengan mengijinkan lesbianisme dan homoseksual (pada non-Yahudi) sekarang ini berarti menolak pro-kreasi yang dipakainya sebagai alasan? Lebih lanjut, mengapa harus adopsi atau inseminasi di tengah-tengah peledakan penduduk yang sedang dikuatirkan hari ini? Dari sisi lain, jika memang peledakan populasi menjadi alasan sehingga homoseks sekarang harus diterima maka apa legitimasi peledakan populasi terhadap praktek homoseksual sehingga praktek itu harus diterima? Relasi populasi dengan praktek homoseksual

\footnotetext{
${ }^{61}$ Nissinen, Homoeroticsm, 19-36, pp.144-52.

${ }^{62}$ Milgrom, Leviticus 17-22, pp.1567-70, 1750, 1786-88.
} 
dan lesbianisme sangat tidak relevan dan tidak berhubungan. adi, tampak dalil pro-kreasi atau alasan perlunya banyak keturunan bukanlah alasan utama, paling tidak bagi Milgrom, sehingga Imamat melarang homoseksual. Hal yang sama juga harus dikenakan untuk alasan penyianyiaan benih kehidupan.

Mengevaluasi ketidakkonsistenan logika Milgrom, sebagai wakil kaum revisionis, saya berpendapat hermeneutis yang diajukannya hanyalah "akal-akalan" belaka.Pertama, dari bagian eksegesis di awal artikel sudah jelas bahwa homoseks dilarang. Pendukung homoseks berusaha mencari arti lain dari bacaan yang sudah amat jelas. Jadi ada kesalahan hermeneutis yaitu mencoba tidak membaca hal yang eksplisit, sebaliknya menekankan bacaan yang implisit. Apa yang dilakukan para penafsir seperti ini adalah mencari celah di mana hukum Imamat bisa dipersalahkan atau tidak valid, sebagaimana praktek penasihat hukum masa kini yang mencari celah di mana bisa lolos dari hukuman. ${ }^{63}$ Kedua, sanggahan fatal untuk alasan pro-kreasi dan penyia-nyiaan benih sebagai dalil larangan homoseks muncul dari konteks Imamat 18 dan 20 itu sendiri. Sanggahan itu adalah larangan terhadap banyak perilaku seks di dalam kedua pasal tersebut.Secara sederhana dapat dijelaskan melalui pertanyaan ini yaitu, mengapa heteroseksual inses tetap dilarang oleh Imamat walaupun tidak ada penyia-nyiaan benih kehidupan dan bisa tetap pro-kreasi? Pertanyaan ini memperlihatkan bahwa pro-kreasi dan penyianyian benih kehidupan bukanlah dua dalil lengkap untuk melarang homoseks atau seluruh perilaku seks dalam konteks Imamat 18 dan 20. Saya berpendapat, di samping alasan pro-kreasi dan kekudusan, kekejian yaitu tebel (pencampuran) adalah alasan lain mengapa Imamat melarang homoseksual, sebab Dia meraja jijik terhadap praktek tersebut (tebel dan tồēbāh).

Homoseks tidak relevan pada saat ini karena larangan homoseks di Imamat 18 dan 20 hanya berlaku bagi orang Israel. Karena alasan ini

\footnotetext{
${ }^{63}$ Gagnon mengkritik Milgrom dalam artikel yang tidak diterbitkannya, A Critique of Jakob Milgrom's Views on Leviticus 18:22 and 20:13" yang bisa dibaca dalam websitenya: www.robgagnon.net/net/articles/homoMilgrom.pdf diakses pada 6 Februari 2015. Dalam artikel ini Gagnon mengkritisi Milgrom dari metodologinya yaitu sumber Holiness yang diasumsikan Milgrom dan "simpati Milgrom" pada kaum LGBT.
} 
maka ada pembatasan aplikasi dari kedua pasal tersebut, dengan kata lain larangan homoseks tidak berlaku pada non-Israel. Argumentasi kaum revisionis, khususnya Milgrom, adalah larangan "berbaring ... seperti dengan seorang perempuan" (miškěbểišāh) dalam Imamat 18:22 ada dalam konteks larangan berhubungan seks dalam keluarga besar (inses). Jadi, homoseks memang dilarang dalam konteks keluarga besar Israel tetapi tidak dilarang bila terjadi di luar relasi keluarga besar. Migrom memahami Imamat 18:22 ini sebagai "do not have sex with a male with whose widow sex is forbidden," lalu ia melanjutkan, "In effect, this means that the homosexual prohibition applies to Ego with father, son, and brother (subsumed in v. 6) and to grandfather-grandson, uncle-nephew, and stepfather-stepson, but not to any other male. "64 Inti yang dikatakan Milgrom adalah hubungan homoseks dengan pria yang tidak ada hubungan keluarga tidak dilarang dalam Imamat. Dengan demikian, homoseksual tidak dilarang di luar Israel, ia hanya dilarang di Israel dan orang-orang yang wajib melakukan hukum-hukum Israel seperti dalam Imamat 18:26. ${ }^{65}$ Jadi ada pembatasan aplikasi larangan homoseks menurut tempat atau etnis, namun pada saat yang sama ada kelonggaran di tempat dan bagi etnis lain.

Membaca lebih jauh alasan Milgrom tentang pembatasan aplikasi larangan homoseks, maka ia mendasarkannya pada analogi aturan tersebut. Secara sederhana gambarannya adalah, larangan hubungan seks heteroseksual terjadi di dalam keluarga (inses) karena akan melahirkan keturunan haram dan hal itu dipandang bersalah. ${ }^{66}$ Akan tetapi, mengapa homoseksual ikut dipersalahkan padahal tidak akan menghasilkan keturunan haram? Atau pertanyaan ini bisa disederhanakan menjadi pernyataan bahwa homoseksual tidak menghasilkan keturunan jadi tidak bisa dipersalahkan. Analogi lain yang ada ialah, jika larangan hubungan seks heteroseksual terjadi di dalam konteks keluarga besar, maka larangan homoseksual harus diperlakukan dalam batasan itu juga, yaitu dilarang dalam keluarga besar tetapi tidak dilarang di luar keluarga besar. Analogi Milgrom keliru, pertanyaan saya adalah mengapa homoseks

\footnotetext{
${ }^{64}$ Migrom, Leviticus 17-22, p.1569.

${ }^{65}$ Ibid., pp.1786-7.

${ }^{66}$ Ibid., p. 1786 .
} 
menjadi salah bisa dilakukan di dalam keluarga padahal tidak dianggap salah bila dilakukan di luar keluarga? Mengapa tempat dan etnis menjadi penentu salah dan benar? Milgrom telah keliru dengan pandangannya sendiri. Pertama, dia telah memisahkan Imamat 18:19-20 dan 22-23 dengan mengategorikan dua bagian ituke dalam bagian larangan terhadap non-keluarga. ${ }^{67}$ Mengapa larangan homoseks dalam Imamat 18:22 tiba-tiba dijadikan larangan untuk keluarga? Jadi Milgrom tidak konsisten dengan pendapatnya sendiri. Kedua, tidak ada petunjuk dalam seluruh PL bahwa pernah ada larangan, homoseks dan hubungan seks ilegal lainnya, dapat dipisahkan menurut etnis pelanggar dan tempat pelanggaran. Larangan homoseks dalam Imamat 18:22 dan 20:13 berhubungan dengan Sepuluh Hukum Musa dan tujuan penciptaan. Dalam PL, khususnya Kejadian 1-2, hubungan seks dilegitimasi dalam pasangan heteroseksual, laki-laki dengan perempuan, tidak ada ruang untuk homoseks atau lesbian dalam legalitas itu. Lalu, PL bersikap tegas bahwa semua orang dihukum Tuhan kalau melakukan pelanggaran, termasuk orang Israel sekali pun. Bahkan, orang Israel yang ada dalam tawanan di negeri asing juga harus mengikuti peraturan seperti yang Tuhan telah nyatakan (bdk. Yeh 18; 33:10-20). Hal yang sama juga diterapkan terhadap bangsa-bangsa lain, di mana orang Mesir dihukum karena perilaku buruk mereka dan dipandang melakukan kekejian. Pada masa belakangan, orang-orang Yahudi dari masa Bait Suci Kedua seperti Philo, Yosefus, para rabi dan orang Kristen mengkritik homoseksual dan lesbianisme. ${ }^{68}$ Ketiga, TDK telah memandang praktek homoseks atau semburit bakti (bdk.Ul 23:17-18) dan praktek pelacur bakti sebagai perbuatan rendah yang pelakunya disebut "anjing."Sementara itu, budaya Asyur menamakan pelaku praktek tersebut sebagai assinnus ("anjinganjing”), bukan karena ritual seksual tetapi karena ada perubahan fungsi maskulin kepada feminim. ${ }^{69}$ Bukti-bukti dari dalam dan luar Imamat memperlihatkan tidak ada pemisahan antara homoseks di dalam keluarga Israel atau di luar, semuanya dipandang sebagai kesalahan.

\footnotetext{
${ }^{67}$ Milgrom, Leviticus 17-22, p.1526.

${ }^{68}$ Lihat lebih lanjut J. J. Collins, Between Athens and Jerusalem: Jewish Identity in the Hellenistic Diaspora (New York: Crossroad, 1986), pp.142-3.

${ }^{69}$ Nissinen, Homoeroticism, pp.28-34.
} 


\section{KEADILAN}

Teks Imamat tidak adekuat melarang homoseksual karena tidak adil. Ada dua hal yang ingin saya klarifikasikan. Pertama kaum revisionis berpendapat bahwa lesbianisme tidak disebut dalam kitab Imamat sehingga praktek itu dipandang tidak melanggar hukum, sebaliknya praktek homoseksual dihukum dan dipandang sebagai kekejian. Kedua, sanksi terhadap homoseksual di dalam Imamat sangat bertentangan dengan standar sanksi dalam masyarakat TDK, misalnya Romawi dan Yunani kuno tidak melarang mutlak homoseksual walau dikecam. Mereka yang mempraktekkan homoseksual hanya dikenakan hukuman menjadi warga kelas dua atau mendapatkan status lebih rendah dari masyarakat lain (dipandang sejajar dengan budak, orang asing atau anak kecil). ${ }^{70}$ Juga di Het, praktek homoseksual tidak dikelompokkan sebagai pelanggaran seks pribadi tetapi pelanggaran terhadap komunitas. Seorang yang melakukan hubungan homoseks dengan anak sendiri akan dihukum mati tetapi tidak demikian bila dilakukan pada orang lain, sanksi sosial akan diterapkan karena menyebabkan kenajisan pada seluruh penduduk lain dan menyebabkan dewa murka. ${ }^{71}$ Kedua situasi ini memperlihatkan ketidakadilan aturan Imamat khususnya dalam praktek homoseksual.

Larangan dalam Imamat 18:22 dan 20:13 jelas merujuk kepada laki-laki (zākār), itulah sebabnya lesbianism sama sekali tidak disinggung. Ada dua hipotesa bisa disebutkan mengapa hanya homoseks yang dilarang. Pertama, dampak praktek homoseksual — khususnya yang bersangkutan dengan ritual dan berasal dari negeri non-Israel-telah melahirkan xenophobia (ketakutan terhadap orang asing) dalam masyarakat. ${ }^{72}$ Ketakutan ini menyebabkan perlawanan yang tampak pada

\footnotetext{
${ }^{70}$ Mitologi Mesir menceritakan dewa Set berhubungan karnal dengan saudara mudanya Horus (W. Westendorf, "Homosexualität.” Lexikon der Ägyptologie. Ed. H.W. Helck. Wiesbaden: Otto Harrassowitz, 1972:2.1272-74). Tentang hukum di Het lihat, H. A. Hoffner, "Incest, Sodomy and Bestiality in the Ancient Near East."Orient and Occident [Fest. C. H. Gordon], ed. H. Hoffner, 81-90. Kevelar: Butzon and Bercher, 1973:85).

${ }^{71}$ Migrom, Leviticus $17-22$, p. 1566.

${ }^{72}$ Selain meresponi kehadiran orang asing di Israel, teks-teks ini juga adalah respons atas urbanisasi dan pandangan lebih kosmopolitan di Israel kuno. Oleh sebab itu ada perubahan ulang kategori dan prioritas yang ada di dalam tradisi, misalnya hadirnya penulis Holiness Code dalam Imamat 20, lihat Phyllis Bird, "The Bible in Christian
} 
serangan homoseksual terhadap orang asing sebagaimana dalam kasus Sodom dan Gomora (bdk.Kej 19) dan Gibeah (Hak 19). Konsekuensi sosiologis ini menciptakan aturan yang berpihak, dalam hal ini hanya kaum homoseks yang dipersoalkan (baik yang menyangkut ritual atau non-ritual), sehingga lesbianisme sama sekali tidak disebut dalam kitab Imamat. ${ }^{73}$ Kedua, agak mengejutkan kalau PL tidak menyinggung lesbianisme padahal praktek ini telah dikenal di TDK. Misalnya, Babilon dan Yunani kuno telah merekam adanya lesbianisme sejak jaman Salomo. ${ }^{74}$ Gestenberger berpendapat bahwa telah terjadi konflik jender karena dalam praktek homoseksual salah satu pria akan berperan pasif. Konflik ini memunculkan misogini (kebencian terhadap perempuan) dan ketakutan irrasional pada kaum laki-laki. ${ }^{75}$ Hipotesa ini didukung oleh perilaku orang Romawi dan Yunani kuno yang menilai seks sejenis pada kaum perempuan dipandang lebih buruk dari seks pria sejenis. Alasannya adalah anggapan bahwa lesbianisme dipandang sebagai menantang supremasi pria. $^{76}$ Dalam rekonstruksi ini, maka tidak heran kalau larangan di Imamat 18 dan 20 hanyalah ditujukan pada homoseks. Akan tetapi, terlepas dari dua hipotesa di atas, inti penolakan terhadap homoseks dalam Imamat adalah perasaan ketidakadilan. Kedua hipotesa justru memperjelas ketidakadilan.

Menurut pendapat saya, perasaan ketidakadilan tersebut tidak tepat karena ada alasan-alasan natural yang mendasari sebuah situasi. Alasanalasan natural bertumpu pada karakter seks natural yang dimiliki laki-laki dan perempuan. Karakter seks natural itu hadir dibalik seluruh peraturan

Ethical Deliberation Concerning Homosexuality: Old Testament Contributions." Homosexuality, Science and "Plain Sense" of Scripture (ed. D. Balch.Grand Rapids: Eerdmans, 2000), p.155.

${ }^{73}$ Baru pada masa rabinik ditambahkan larangan terhadap lesbianisme, lihat The Code of Maimonides: The Book of Holiness (Book V) (terj. L.I. Rabinowitz dan P. Grossman. New Haven: Yale University, 1965), p.135.

${ }^{74}$ Lihat J. Bottéro dan H. Petschow “Homosexualität.”RLA 4 (1975), 459-68 yang menulis tentang karya penyair lesbian Sappho, lahir kira-kira 612 B.C.E., berasal dari pulau Lesbos yang menjadi asal kata lesbian.

${ }^{75}$ E. S. Gestenberg, Leviticus (trans. D. W. Stott. Louisville: Westminster-John Knox, 1996), p.297.

${ }^{76}$ Bird, "Christian Ethical Deliberation," p.152. 
dalam Imamat 18. Apa karakter seks natural yang dimaksud dan bagaimana dia bekerja?

Karakter seks natural terdapat dalam diri setiap orang untuk menentangnya mendapatkan seks dari dagingnya sendiri. Dengan kata lain, pemenuhan seksual pria bukanlah berasal dari jendernya sendiri tetapi dari jender berbeda yang menyebabkan adanya komplementari satu dengan yang lain. Karakter seks natural ini merujuk kepada seksualitas jender dalam penciptaan di Kejadian 1 dan 2. Perbedaan jender dipandang sebagai komplemen satu dengan yang lain.

Struktur larangan dalam Imamat 18 memperlihatkan karakter seks natural ini. Imamat 18:6 melarang seorang laki-laki berhubungan seksual dengan kerabatnya sendiri/inses. Karakter ini muncul pada larangan lain misalnya pada perempuan menstruasi dan pada hubungan seks dengan hewan. Larangan meniduri perempuan menstruasi (Im 18:19) bukanlah karena persoalan otoritas laki-laki lebih unggul atau sebaliknya, melainkan memberikan kesempatan kepada tubuh perempuan untuk secara alamiah membarui dirinya sendiri. Dasar di balik larangan ini adalah agar perempuan menjadi perempuan yang sesungguhnya. Sebab saat perempuan menstruasi dia mendapatkan kesempatan dibebaskan dari “penyerobotan seorang laki-laki."Larangan berkelamin saat menstruasi menjaga karakter seks natural wanita dan gagasan memelihara karakter seks natural itu ada juga pada larangan homoseksual, yaitu biarlah lakilaki menjadi laki-laki ("bukan perempuan” dalam hubungan seks sejenis).

Larangan berkelamin dengan hewan (Im 18:23) juga merujuk kepada karakter seks natural. Sama seperti larangan mencampurkan dua jenis spesies hewan atau tumbuhan berbeda (Im 19:19) yang tidak dapat disatukan. Motif mencampurkan dua hal yang berbeda dipandang juga sebagai tidak natural, tidak sesuai tujuan semula ketika diciptakan. Dengan demikian "hubungan yang tidak sepadan" dilarang dalam seluruh Imamat 18 dan 20 karena bertentangan dengan karakter seks natural (kakek-cucu, menantu-mertua, tante-keponakan, saudara-saudari, dan seterusnya). Seorang pria tidak boleh berhubungan seksual dengan istri tetangga (Im 18:20), yang bisa juga berimplikasi seorang pelacur, adalah 
membatasi supaya seorang laki-laki memiliki hubungan seks dengan istrinya sendiri karena inilah karakter seks naturalnya. Jadi aturan dalam Imamat 18 dan 20 bukan persoalan dominasi dan jender-yang menyinggung rasa keadilan, aturan ini berkeinginan menjaga karakter seks natural yang bisa melenyapkan dominasi satu terhadap yang lain.

Penulis merasa perlu menyebutkan beberapa teks PB untuk menunjukkan bahwa isu ketidakadilan adalah salah dalam kaitannya dengan larangan homoseksual di kitab Imamat. Pertama, dalam perspektif 1 Korintus homoseks dilarang karena berasal dari nafsu berahi diri (1 Kor 6:1-20, khususnya ay. 18). Paulus memakai dua kata,malakos ${ }^{77}$ (juga di 1 Tim 1:10) dan arsenokoitai dalam 1 Korintus 6:9. Kata malakos koheren dengan ajaran Imamat 20:13, demikian pula kata arsenos yang dipakai secara eksplisit dalam LXX Imamat 20:13 dan 18:22. Jadi amat mungkin berasumsi bahwa Paulus dipengaruhi kitab Imamat ketika membahas masalah homoseksual di 1 Korintus 6:9 dan juga di Roma 1:27 yang akan kita lihat nanti. Pada sisi lain, para rabi juga memakai kata Ibrani (Im 18:22 dan 20:13) yang sama seperti yang dipakai penerjemah LXX untuk menerjemahkan malakos dan arsenos. Kedua kata ini tidak mudah diterjemahkan, ${ }^{78}$ namun cukup jelas isu sentral dalam 1 Korintus 6 adalah

\footnotetext{
${ }^{77}$ Kata ini berarti "halus" atau "lembut" yang dipakai untuk seorang laki-laki yang kewanitaan, pasangan pasif dalam homoseksual, pelacur pria, dan orang yang hidup dengan standar moral yang rendah. Jadi kata ini bersifat umum, ia bisa dipakai ketika pelacur pria berpembawaan wanita atau merujuk kepada pria muda yang berperan pasif dalam homoseks. Menurut Wee, dalam 1 Korintus 6:11 kata malakos ini merujuk kepada pasangan pasif dalam homoseksual atau pelacur pria. Secara khusus, ayat ini memakai dua kata malakos dan arsenokoitēs secara berdampingan.Pemakaian ini berfungsi sebagai merisma (sepasang kata berlawanan supaya bisa mengungkap sebuah ide yang utuh).Arsenokoitēs tidak merujuk kepada hubungan seksual antara pria.Ia lebih menunjuk kepada hubungan seksual pria lebih tua terhadap pria lebih muda. Jadi, pria yang mengeksploitasi pria lain melalui hubungan seks, lihat CSTCSRM,p.20.

${ }^{78}$ Terjemahan Baru edisi ke-2 (TB 2) menerjemahkan kedua kata ini dengan "laki-laki yang bersetubuh dengan sesama jenisnya, pasangan orang yang berbuat demikian.”Terjemahan Baru tahun 1974 (TB 1974) menerjemahkan "banci, orang pemburit."Tampak TB-2 cukup diplomatis dengan tidak menjelaskan mana pihak yang aktif dan mana yang pasif dalam homoseks, sementara TB 1974 cukup jelas menyebut pihak aktif dalam homoseks ("orang pemburit") tetapi ambigu ketika memperlakukan kata malakos ("banci", bisa aktif atau pasif). Terjemahan NIV berbunyi "male prostitutes nor homosexual offenders." Terjemahan ini memberi kemungkinan bahwa malakos adalah pelacur laki-laki yang homoseks dan sekaligus heteroseks; sementara arsenokoitēs dimaknai umum (bisa aktif atau pasif).Tidak dapat dipastikan apakah
} 
soal pengendalian diri dan arogansi. ${ }^{79}$ Jadi Paulus justru sedang melawan ketidakadilan yang tampak dalam hadirnya homoseks di 1 Korintus, dan Paulus juga menentang mereka yang didorong nafsu berahi karena tidak sesuai dengan karakter seks natural mereka. Adalah jelas juga bahwa 1 Korintus 6:9 dan 1 Timotius 1:10 tidak menyebut tentang larangan lesbianisme. Seandainya Paulus mencantumkan larangan itu pada kedua teks ini, maka alasan Paulus pastilah sama dengan alasan dia melarang homoseksual yaitu dorongan nafsu berahi.

Kedua, jika diterima Roma 1:26menggemakan Imamat 18 dan 20, maka dapat dipastikan bahwa Paulus juga memahami Imamat melarang lesbianisme. Sebab di Roma 1:26, dia terang-terangan melarang lesbianisme. Larangan lesbianisme di kitab Roma mencakup seluruh bentuk praktek tersebut, sebab dalam dunia Greko-Roma lesbianisme memiliki beragam bentuk dan umumnya bukan karena eksploitasi. ${ }^{80}$ Sementara itu, dalam ayat 27, Paulus melarang homoseksual yang kemungkinan besar adalah praktek homoseks terhadap remaja laki-laki (pederasty) yang umum terjadi pada masa itu. Larangan lesbianisme dan homoseksual dalam kedua ayat ini, menurut konteksnya, harus dipahami sebagai penyebab Tuhan murka sekaligus sebagai bentuk hukuman itu sendiri. ${ }^{81}$ Jadi Paulus menyangkal lesbianisme dan homoseksual, tanpa membedakan pihak yang mengeksploitasi atau yang sedang dieksploitasi. Teks Roma ini membuktikan bahwa lesbianisme dilarang sama seperti homoseks, sehingga anggapan bahwa hanya homoseks yang dilarang adalah tidak benar. Juga Paulus berpendapat bahwa homoseks dan lesbianisme adalah bentuk hukuman Tuhan.

Oleh sebab itu, pandangan bahwa kitab Imamat tidak adekuat melarang homoseksual karena lesbianismetidak disebut dan adanya perbedaan hukuman dari yang dipraktekkan di TDK tidak dapat diterima.Walau kitab Imamat tidak menyebutkan larangan lesbianisme,

\footnotetext{
kedua kata di atas merujuk homoseks saja, atau bisa homoseks-heteroseksual ilegal, juga tidak dapat diketahui mana pihak yang aktif dan pasif.

${ }^{79}$ Robert A. J. Gagnon, “A Comprehensive and Critical Review Essay of Homosexuality, Science, and the 'Plain Sense' of Scripture.” HBT 22:2 (Dec. 2000), pp.174-243.

${ }^{80}$ CSTCSRM, p. 20 .

${ }^{81}$ Ibid.
} 
namun 1 Korintus 6 dan Roma 1 secara jelas sejalan dengan pikiran Imamat 18 dan 20. Pengaruh Imamat terlihat jelas dalam pikiran Paulus tentang homoseksualitas. Lagi pula, hukuman di Imamat tidak perlu sama dengan dengan yang berlaku di TDK, sebab hukum Imamat didasarkan pada diri Allah sendiri "Akulah TUHAN" bukan hanya sanksi masyarakat.

\section{SIMPULAN}

Dari sisi eksegesis, teks dan konteks Imamat 18:22 dan 20:13 jelas melarang hubungan homoseks. Akan tetapi, cara memahami teks dan konteks, serta bagaimana seharusnya berita itu dapat diterima orang masa kini telah menjadi penghalang untuk menerima berita harfiah kedua teks tersebut. Hal ini jelas terlihat dari keberatan-keberatan hermeneutis yang didiskusikan dan telah dijawab dalam artikel ini.

Posisi artikel ini telah dinyatakan yaitu mengafirmasi aturan larangan homoseks ini. Sepuluh Hukum Musa dan bagian-bagian Pentatukh lainnya menjadi landasan larangan homoseksual, demikian pula kecaman dan hukuman yang digambarkan untuk perbuatan homoseks (dan perbuatan seksual lainnya) memperlihatkan bahwa praktek itu adalah pelanggaran serius. Pelanggaran ini bukan hanya berelasi dengan kekudusan ritual tetapi juga moral,di samping itu faktor "pencampuran" menjadi sebuah alasan lain mengapa homoseks dilarang. Gagasan heteroseksual, tujuan ilahi seks dan karakter seks natural yang disebutkan dalam kisah Penciptaan juga meneguhkan larangan praktek homoseksual. Pada dasarnya, pelanggaran homoseksual adalah perlawanan terhadap pribadi Allah sendiri, yang menyebutkan "Akulah TUHAN" sebagai motif seluruh aturan Imamat.

Tidak mengherankan pula kalau pelanggaran homoseks dihukum, bahkan lebih berat dari hukuman yang dikenakan oleh masyarakat TDK. Hukuman itu berstandar pada diri TUHAN sendiri. Hukuman itu tidak pandang bulu, Israel dan non-Israel dihukum. Juga tidak pandang tempat dan siapa yang melakukannya. 
Larangan praktek homoseks tidak hanya disebut oleh kedua teks Imamat yang telah dibahas di atas, tetapi juga dikonfirmasi PB. Dalam konteks ritual dan moral, Paulus menilai homoseks sebagai bentuk hukuman Allah sekaligus cara Allah menghukum. Gagasan Paulus tentang homoseks koheren dengan kedua teks Imamat yang dibahas. Para penulis pra-Paulus dan penerus Paulus, seperti para penulis Yahudi dan Kristen, secara konsisten menolak homoseks. Penulis berpendapat bahwa gereja-gereja di Indonesia juga dapat mengadopsi posisi yang telah penulis uraikan di atas.

\section{DAFTAR RUJUKAN}

Albright, W. F. From Stone Age to Christianity. Baltimore: John Hopkins, 1957.

Bast, Rose Ann. "Homosexuality." International Encyclopedia of Ethics. Ed. John K. Roth.London-Chicago: Fitzroy Dearborn, 1995: 39497.

Biale, D. Eros and the Jews. New York: Basic Books, 1992.

Bigger, S. F. "The Family Laws of Leviticus 18 in Their Setting." JBL 98 (1979), 187-203.

Bird, Phyllis. "The Bible in Christian Ethical Deliberation Concerning Homosexuality: Old Testament Contributions." Homosexuality, Science and "Plain Sense" of Scripture. Ed. D. Balch. Grand Rapids: Eerdmans, 2000.

Boswell, J. Christianity, Social Tolerance, and Homosexuality. Chicago: University of Chicago, 1980.

Bottéro, J. dan Petschow, H. “Homosexualität.” RLA 4 (1975), 459-68.

Carmichael, Calum M. Law, Legend, and Incest in the Bible: Leviticus 18-20. Ithaca: Cornell University, 1997.

Collins, J. J. Between Athens and Jerusalem: Jewish Identity in the Hellenistic Diaspora. New York: Crossroad, 1986. 
Daube, D. "Codes and Codas in the Pentateuch." Juridical Review 53 (1941), 242-61. Studies in Biblical Law. Cambridge: CUP, 1947.

D. P. Wright, D. N. Freedman, Avi, Huvitz (Editor)."Poetic Structure in Leviticus" Pomegranates and Golden Bells: studies in biblical, Jewish, and Near Eastern ritual, law, and literature in honor of Jacob Milgrom. Winona Lake: Eisenbrauns, 1995, 239-56.

Douglas, M. "The Stranger in the Bible." Archives europeénnes de sociologie 35 (1994), 283-98.

Purity and Danger. London: Routledge \& Kegan Paul, 1966.

"Sacred Contagion" Reading Leviticus (ed. J. F. A. Sawyer). Sheffield: Sheffield Academic Press, 1996: 86-106.

Dover, K. J. Greek Homosexuality. Cambridge: Harvard University Press, 1989.

Eilberg-Schwartz, H. The Savage in Judaism. Bloomington: Indiana University Press, 1990.

Elliger, K. "Das Gesetz Leviticus 18." ZAW 67 (1955): 1-24.

Fee, Gordon. New Testament Exegesis. Terj. Andreas Hauw. Malang: Literatur Saat, 2011.

Gagnon, Robert A. J. "A Comprehensive and Critical Review Essay of Homosexuality, Science, and the 'Plain Sense' of Scripture." HBT 22:2 (Dec. 2000), 174-243.

The Bible and Homosexual Practice. Texts and Hermeneutics. Nashville: Abingdon, 2001. "The Old Testament and Homosexuality: A Critical Review of the Case Made by Phyllis Bird." ZAW 117. BD. , S. (2005), 367-94.

A Critique of Jakob Milgrom's Views on Leviticus 18:22 and 20:13" dalam www.robgagnon.net/net/articles/homoMilgrom.pdf diakses pada 6 Februari 2015.

Geller, M. J. “Taboo in Mesopotamia.” JCS 42 (1990), 105-17. 
Gesteberg, E. S. Leviticus. Terj. D. W. Stott. Louisville: WestminsterJohn Knox, 1996.

Gesenius' Hebrew Grammar. Ed. E.Kautzsch, terj. A.E. Cowley, edisi kedua. Oxford, 1910.

Gottwald, N. K. The Tribes of Israel: A Sociology of the Religion of Liberated Israel, 1350-1050 B.C.E. Maryknoll: Orbis, 1979.

Greenberg, David F. The Construction of Homosexuality. Chicago: University of Chicago Press, 1988.

Harrison, R. K. Leviticus. TOTC. Leicester: Inter-Varsity, 2002.

Hartley, John E., Leviticus. WBC 4. Dallas: Word Books, 1992.

Hill, Andrew E. dan Walton, John H. A Survey of the Old Testament. Edisi ke-2. GrandRapids: Zondervan, 2000.

Hoffmann, D. Z. Leviticus. Terj. Z. Har-Shafer dan A. Lieberman. Jerusalem: Mosad Harav Kook, 1954.

Hoffner, H. A. "Incest, Sodomy and Bestiality in the Ancient Near East." Orient and Occident [Fest. C. H. Gordon]. Ed. H. Hoffner. Kevelar: Butzon and Bercher, 1973.

Horgan, John. "Eugenic Revisited." Scientific American 268 (June, 1993): 122-131.

Joüon, Paul dan Muraoka, Takamitsu. A Grammar of Biblical Hebrew. Cet. ke-2, edisi ke-2. SB 27. Roma: Gregorian \& Biblical Press, 2009.

Kaiser, Walter C. The Book of Leviticus. NIB 1. Ed. Leander E. Keck, dkk. Nashville: Abingdon, 1994.

Kelley, Page H. Pengantar Tata Bahasa Ibrani Biblikal. Terj. Andreas Hauw. Surabaya:Momentum, 2013.

Kilian, R. Literarkritische und formgeschichtliche Untersuchung des Heiligkeitsgesetezes. Bonn: Haustern, 1963. 
Klostermann, A. "Ezechiel und das Heiligkeitsgesetz." Der Pentateuch: Beiträge zu seinem Verständnis und seiner Entstehungsgeschichte. Leipzig: U. Deichert'sche Verlagsbuchhandlung, 1893.

LeVay, Simon. "A Difference in Hypothalamic Structure Between Heterosexual and Homosexual Men." Science 253 (August 30, 1991): 1034-1037.

Levine, Baruch A. Leviticus. JPSTC. Ed. Nahum M. Sarna and Chaim Potok. Philadelphia: TheJewish Publication Society, 1989.

Looy, Heather dan Bouma III, Hessel, "The Nature of Gender: Gender Identity in Persons Who are Intersexed or Transgendered." Journal of Psychology and Theology Vol 33 No. 3(2005): 166-178.

Malchow, Bruce V. "Scripture as a Norm of Moral Deliberation and Its Application to Homosexuality." Currents in Theology and Mission 31:6 (2004), 465-72.

Milgrom, Jacob. Leviticus 17-22, AB 3A. New York: Doubleday, 2001.

Mirkes, Renée. "Science, Homosexuality, and the Church." Ethics and Medics 17 (June, 1992): 1-3.

Nissinen, Martti. Homoeroticism in the Biblical World: A Historical Perspective. Minneapolis: Augsburg Fortress, 1998.

Olyan, S. M. "And with a Male You Shall Not Lie the Lying Down of a Woman": On the Meaning and Significance of Leviticus 18:22 and 20:13. Journal of the History of Sexuality 5 (1994), 179-206.

Phillips, A. J. "Some Aspects of Family Law in Pre-exilic Israel." VT 23 (1973), 349-61.

Philo. On the Special Laws. Terj. F.H. Colson dan G.H. Whitaker. 2 jilid. Loeb Clasical Library.Cambridge: Harvard University Press, 1937.

Picket, W. The Meaning and Function of $T^{c} B / T O^{c} E B A H$ in the Hebrew Bible. Ph.D. diss.,Hebrew Union College, 1989.

Preuss, H. D. "תזצבה"TDOT 15:602. 
Rattray, S. "Marriage Rules, Kinship Terms and Family Structure in the Bible.” SBLSP 26. Ed. K. Richards. Atlanta:Scholars, 1987.

Snaith, N. H. Leviticus and Numbers. London: Nelson, 1967.

Stager, L. E. "The Archeology of the Family in Ancient Israel." BASOR 260 (1985): 1-35.

The Code of Maimonides: The Book of Holiness (Book V). Terj. L. I. Rabinowitz dan P.Grossman. New Haven: Yale University, 1965.

Thurston, T. M. "Leviticus 18:22 and the Prohibition of Homosexual Acts." Homophobia and the Judaeo-Christian Tradition. Ed. M. L. Stemmeler dan J. M. Clark. Dallas: Monument, 1990:7-23.

van der Toorn, K. Family Religion in Babylonia, Syria and Israel. Leiden: Brill, 1996.

Waltke, Bruce K. dan O'Connor, M. An Introduction to Biblical Hebrew Syntax. Winona Lake: Eisenbrauns, 1990.

Weingreen, J. A Practical Grammar for Classical Hebrew. Edisi ke-2. Oxford: Clarendon, 1959.

Wenham, Gordon J. The Book of Leviticus. NICOT. Grand Rapids: Eerdmans, 1979.

Westendorf, W. "Homosexualität.” Lexikon der Ägyptologie. Ed. H. W. Helck. Wiesbaden: Otto Harrassowitz, 1972:2.1272-74.

Wright, C. J. H. Old Testament Ethics for the People of God. Nottingham: Inter-Varsity, 2004. "Sex in Leviticus: It's Part of a much Broader Teaching in Scripture." Christianity Today (July/August, 2013), 33.

Ziskind, J. R. "The Missing Daughter in Leviticus XVIII.” VT 46 (1996). 127-28.

\section{SUMBER INTERNET}

http://www.churchofscotland.org.uk/data/assets/pdf_file/0014/13811/20_ THEOLOGICAL_2013.pdf diakses 4 februari 2015 
38 Teks, Konteks dan Hermeneutika Imamat 18:22

http://regional.kompas.com/read/2014/10/31/0730008/Dua.Gadis.Gowa.

Diamankan.karena.Ingin.Menikah.Sesama.Jenis?utm_source=WP \&utm_medium=box\&utm_campaign=Kknwp

http://info.ncss.org/joom837/index.php/m-statements/84-statement-onpink-dot-25-jun-2014

http://www.straitstimes.com/news/singapore/more-singapore-

stories/story/nlb-saga-two-removed-childrens-books-will-go-adultsecti

http://pinkdot.sg/about-pink-dot/ 